\title{
The Relation between Scenes and Texts of the Book of the Gates and Amduat applied on Seti I Tomb
}

\section{Mohamed Ragheb Dardir}

$\mathrm{PhD}$.

\begin{abstract}
This paper investigated the relation between the Book of Gates and the Book of Amduat applied on the tomb of king Seti I (KV17) According to Piankoff (1962) statement that the scenes of the first 5 divisions of the Book of Gates related to the first 6 hours of the Book of Amduat, Regen, (2014) highlighted the relation between scenes of the $1^{\text {st }}$ and $2^{\text {nd }}$ of the version without illustration of the book of Amduat and the $1^{\text {st }}$ and the $2^{\text {nd }}$ division of the book of Gates on the tomb of (Pedeamenope TT33).
\end{abstract}

Keywords: 6 hours Amduat, 5 Divisions Book of Gates, Seti I Tomb.

\section{Introduction}

The existence of the two Underworld books (Amduat, Book of Gates) depicted on the wall of the tomb of Seti I it was a theological composition appeared for the first time on the royal tombs' funerary scenes depiction. So, in this study the researcher will highlight the relation between the two books and the funerary cult reasons for the appearance of the Book of Gates beside the book of Amduat (Ali-Mahfouz, 2016). Piankoff stated that on the tomb of king Seti the first 6 hours non illustrated version of Amduat related to the first 5 division of the Book of Gates .it was a part of Theological funerary composition which are the book of Amduat, the litany of the sun, the Book of Gates, this statement means that the Book of Amduat alone at the beginning of the 19 dynasty was not sufficient to achieve the royal funerary requirement which is summarized in his resurrection with Re during his journey in the underworld (Piankoff, 1962)

(Sadek, 1985) studied the late version of the book of Amduat, he highlighted that the theological cosmic content of the Book of Amduat was to fulfill the fundamental funerary requirement for the royal funeral cult. Therefore, the first 8 hours of Amduat concern the funeral rites which apply only to the kings. Nevertheless, the last four hours of the Amduat concern the sun god cosmic procession during his journey in the underworld.

Regen (2014) discussed in her researches the relation between some hours of the book of Amduat and some division of the Book of Gates which was forgotten by (Piankoff, 1962), applied on some scenes from the tomb of Pedeamenope (TT33), when she studied the first and second division of both books, she find the similarity in the domain or the fields of the procession of the solar boat of both middle register scenes of the $1^{\text {st }}$ and $2^{\text {nd }}$ hours Amduat and the $1^{\text {st }}$ and $2^{\text {nd }}$ division of the Book of Gates and the similarity in the main theme and the context of both of them.

\section{Literature review}

The appearance of the Book of Amduat

The Book of Amduat without illustration appears for the first time on the wall of the tomb of king Thoutmosis I (KV38), the complete version of Amduat is shown on the tomb of king Thoutmosis III (KV34), (Hornung \& Christian, 2006), on the tomb of Amenophis II (KV35) and the tomb Amenophis III (KV22) (Piankoff \& Hornung, 1966), the Book of Amduat was called the Book of the Hidden Chamber (Bucher, 1931). The Amduat without illustration appears for the first time on the tomb of Thoutmosis I. Nevertheless, the Book of Amduat was not existed in the tomb of Hermoheb and Ramses I instead of it the Book of the Gates replaced it for the first 
time (Piankoff, 1962). Otherwise on the tomb of Tutankhamun (KV62), it was depicted the first hour only (Piankoff, 1952). but on the tomb of king Hermoheb the Book of Amduat was replaced by some division of the Book of Gates. (Hornung \& Teichmann, 1971)

The Amduat was a composition both theological and funeral, it was a result of a long evolution of Egyptian religious and funeral conception which were closely related to the origin of the Ancient Egyptian religion. The first theme of the Book of Amduat is the funeral conception aimed to achieve the funerary requirement for the deceased in the hereafter which connect with the destiny of the soul of the King when he enters the underworld. (Sadek, 1985).

The Book of Amduat describe the solar god journey in the underworld during the 12 hours of the night in which the sun god is regenerated to be reborn at down (Barguet, 1972). According to the Ancient Egyptian cosmogony conception, goddess Nut, the personification of the sky, swallow the sun god each day at dawn to give birth to him in the early morning this nighty journey of the sun occurs inside the body of goddess Nut, occurs also "in the underworld" when the rebirth of the sun god is to be occurs in the underworld, thus it serves the funerary cult of the dead (Piankoff, 1934).

Pirenne (1965) gave a good explanation for the theological Solar theme of the Book of Amduat which relates to the Ancient Egyptian cosmogony conception, is that the Amduat describes the journey of the sun god in the underworld which is an explication of metaphysical of the journey of the sun during the nighty journey in the underworld describing the gods and the creative who are there.

Barguet (1972) highlighted the benefit of the book of Amduat for the royal funerary cult, that it is a composition of a royal funerary conception according to the solar symbolism, thus, the first 8 hours of Amduat concern the funeral rites which only apply to kings. However, the last 4 hours which has a solar symbolism adapted to the underworld domain.

The text accompanied the scenes of Amduat deals with the main funerary theme of Amduat which is connected with the procession of the sun god and the soul of the king accompanied him during the journey of the sun god in the underworld, the text only mentioned the names of the gods who are in the domain of each hour (Hornung, 1964) each hour of Amduat without illustration (Hornung, 2007) include one or more sentence explaining what is going on in each hour to know the soul of the King the names of the deities. Therefore, Amduat without illustration existed in the royal tombs next to the complete version Amduat. Therefore, the benefits of the first 8 hour which was depicted in the book of Amduat without illustration comprising funeral theme for the deceased King can be summarized in, the soul of the king in the procession of the navigator's solar god boat will allow him to cross the underworld river "Wrns" before reaching the necropolis avoiding the pitfalls, therefore the Amduat without illustration is a Solar Nautical guide for the benefits of the soul of the deceased in the underworld (Hornung, 1964).

Sadek (1985) gave a good explication why the Amduat without illustration was depicted beside the complete version Amduat so that the funeral contents of the Amduat without illustration was completed the 8 hours scenes of the complete version Amduat which is a complete funeral theme symbolizing the regeneration of the Sun during the nighty journey in the underworld thus ensure the rebirth of the soul of the king with the sun god, nevertheless the Amduat without illustration and the completed Amduat was depicted separately comprising the funeral theme.

According to Piankoff (1962) on the wall of tomb of Seti I (KV17) it was depicted 11 hours of the complete Amduat plus the first 6 hour of the of Amduat without illustration related to the first 5 division of the book of Gates (Hornung, 1992). 


\section{The Appearance of the Book of Gates at the end of the $18^{\text {th }}$ Dynasty and its benefits for the deceased.}

The Book of Gates appears in three version, the first version not completed, its first appearance was on the wall of the tomb of Horemheb (KV59) at the end of the $18^{\text {th }}$ dynasty. The second appearance of the first version was on the wall of the tomb of Ramses I (KV16) at the beginning of the $19^{\text {th }}$ dynasty, the third appearance of the first version was on the wall of the tomb of Seti I (KV17) (Lefebure,.1884; Hornung, 1991) The second version dates back to the reign of Merenptah on the right wall of the entrance corridor of the Osireion (Frankfort, 1933), the third complete version on the left wall of the corridors A, B, C, and the salle (D) in the tomb of Ramses IV (KV2) (Piankoff, 1954). The scenes of the Book of Gates which is depicted on the wall of the Tomb of Ramses VI is considered one of the best and complete versions of the Book of Gates (Mahfouz, 2016).

According to Piankoff (1957), the Book of Gates was divided into three main sections: the first section (initial division) describes the solar boat enters the western mountain, the $1^{\text {st }}$ and $2^{\text {nd }}$ division was depicted on the wall of the burial chamber of Ramses I. The second section of the Book of Gates include scene of the judgment of Osiris $5^{\text {th }}$ division was depicted on the lid of the Sarcophagus of king Seti I (19 ${ }^{\text {th }}$ dynasty) which is now in Soane Museum at London (no. PJ 1551.05). (Tylor, 2017). The third section of the Book of Gates depicting god Noun raising up the new born sun god getting out of the Primeval Ocean from Papyrus marches "the mythology Papyrus" (Piankoff, 1957). Hornung (2014) entitled the Book of Gates as "The Book of Hell" due to the guardian god of each gate who took the form of a serpent. (Leitz, 2002), otherwise, it is distinguished by the existence of only two gods accompanied the solar boat of god Re in his journey, god si3 in fore part of the solar boat and god "hw". (Ali, 2010) at the rear part of the boat (Piankoff, 1939; Hornung).

The middle register of the divisions of the Book of Gate contains the main scene, represents the Solar boat during his procession in the domain or fields of the underworld, when the Solar boat reaches the final $12^{\text {th }}$ Gate, He will be reborn in the form of god Khepri, then he completes his journey in another boat in the Eastern Horizon of the sky during the day (Schweizer \& Hornung, 1994; Manassa, 2006). The first hour of the underworld is considered the waiting phase to enter the underworld, while the $12^{\text {th }}$ hour representing getting out of the underworld to be reborn (AbdEl Hady, 2002).

It was determined by Piankoff (1962) and Tylor (2010) that the first 6 hours of Book of Amduat without illustration is related to the first 5 divisions of the Book of Gates to illustrate the risks of the journey of the sun god accompanied by the soul of the deceased in the Underworld and how to overcome the dangers of the evil spirits. 
Fig.1: The layout of the Tomb of Seti I and the distribution of the scenes of the Book of Amduat and the Book of the

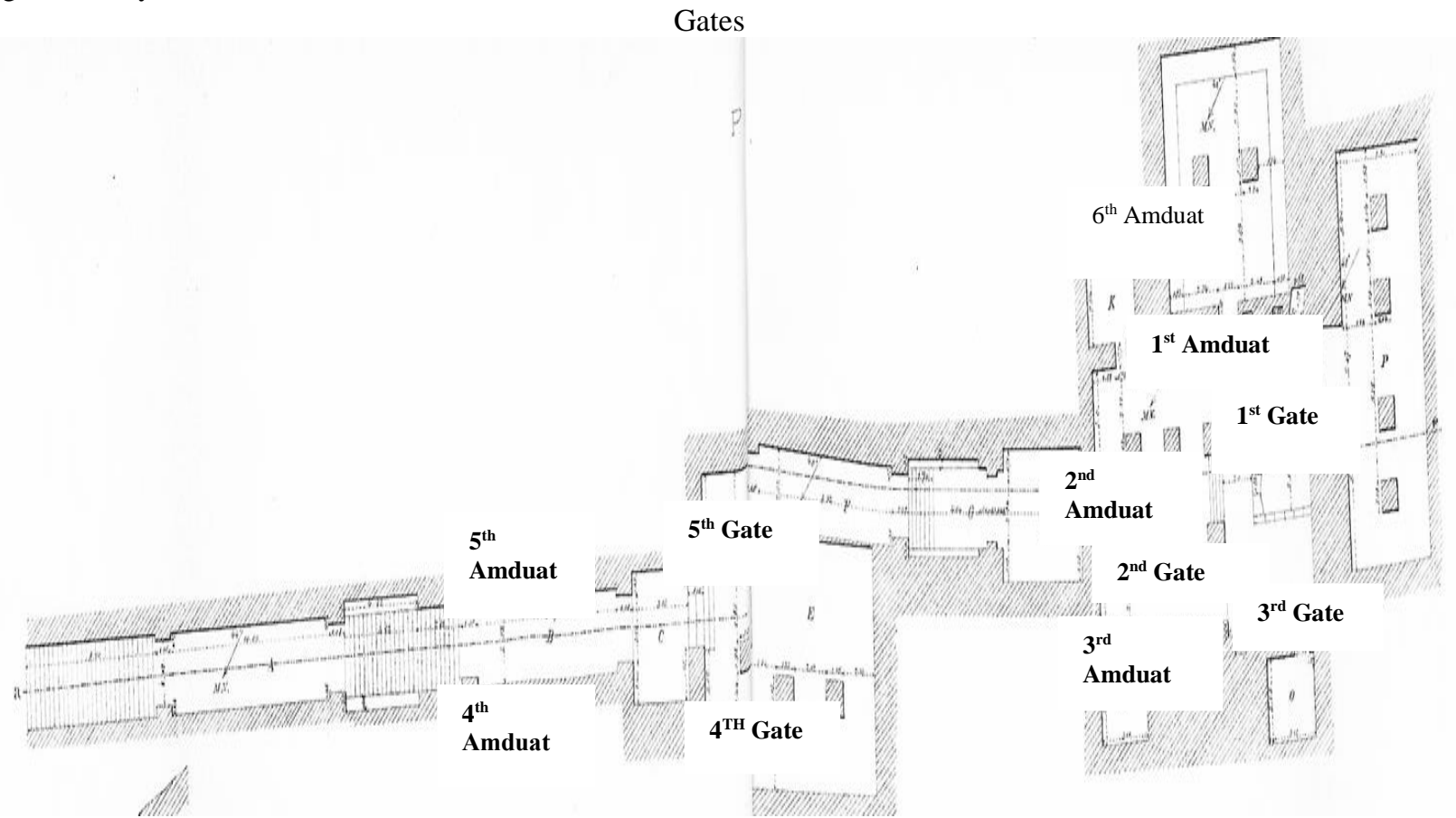

cf. Lefébure, G. (1884) Le Tombeau de Seti I, MMAF. II, pl. I; Hornung, E. (1991). The Tomb of Seti I, Zurich Pl.1.

The distribution of the scenes of Amduat and book of Gates on the wall of the tomb Seti I (KV17) according to (fig. 1)

- The $1^{\text {st }}$ hour of the book of Amduat, on the left wall of the inner part of the burial chamber $(\mathrm{K})$, three register (scene 1,2).

- The $1^{\text {st }}$ division of the book of Gates, on the western wall of the inner part of the burial chamber $(\mathrm{K})$ three register (scene 1,2,3)

- The $2^{\text {nd }}$ hour Amduat, on the Western wall of the inner part of the burial chamber $(\mathrm{K})$ three register (scene 3, 4, 5)

- The $2^{\text {nd }}$ division of the book of Gates, on the Eastern wall of the inner burial chamber $(\mathrm{K})$, three register (scene $4,5,6$ )

- The $3^{\text {rd }}$ hour Amduat, on the Eastern wall of the forepart of the burial chamber $(\mathrm{J})$, three register (scene 6, 7, 8)

- The $3^{\text {rd }}$ division of the book of gates, on the left wall of the Annexed room (L) right to the burial chamber, three register (scene 7, 8, 9)

- The $4^{\text {th }}$ hour Amduat, on the right wall of the $3^{\text {rd }}$ Corridor $(C)$ at the first main Axe of the tomb, three register (scenes $9,10,11$ )

- The $4^{\text {th }}$ division of the book of gates on the 4 Pillared Hall (E) of the $1^{\text {st }}$ Axe of the tomb. three register (scene 10,11,12)

- The $5^{\text {th }}$ hour book of Amduat on the left wall of the $3^{\text {rd }}$ corridor of the tomb, 3 register (scene $12,13,14)$ 
- The $5^{\text {th }}$ division of the Book of Gates on the 4 pillared Hall (E) at the beginning of the $2^{\text {nd }}$ axe of the tomb, three register (scene 13,14,15), the scene of the judgment of Osiris on the gate door of the $5^{\text {th }}$ division (scene 16)

- The $6^{\text {th }}$ hour Amduat, on the Eastern wall of the $2^{\text {nd }}$ annexed room $(\mathrm{M})$ to the left of the burial chamber (scene 15, 16, 17)

\section{The $1^{\text {st }}$ hour of the book of Amduat}

On the left wall of the Burial Chamber $(\mathrm{K})$ (Lefebure, 1884) during the $1^{\text {st }}$ hour of the Book of Amduat, the sun god in the form of god Khepri enters the gate of the underworld after the sunset according to the text " (Hornung, 2007).

According to Bucher, the Tomb of King Seti I does not contain all the same figure complete of the $1^{\text {st }}$ and $2^{\text {nd }}$ and $3^{\text {rd }}$ scenes of the hours of Amduat which was represented completely on the wall of the tomb of Tutmosis III and Amenophis I and it missed some of the figures of creative of the underworld (Bucher, 1931), but the text accompanied these scenes is similar to the text accompanied the first 3 hours of Amduat on the tomb of Thoutmosis III and Amenophis II. The upper register of the $1^{\text {st }}$ hour of Amduat is a text describing the sun god in the form of god Khepri in his Solar boat while enters the gate of the underworld after the sunset.

Fig.2: The $1^{\text {st }}$ Hour of the Book of Amduat

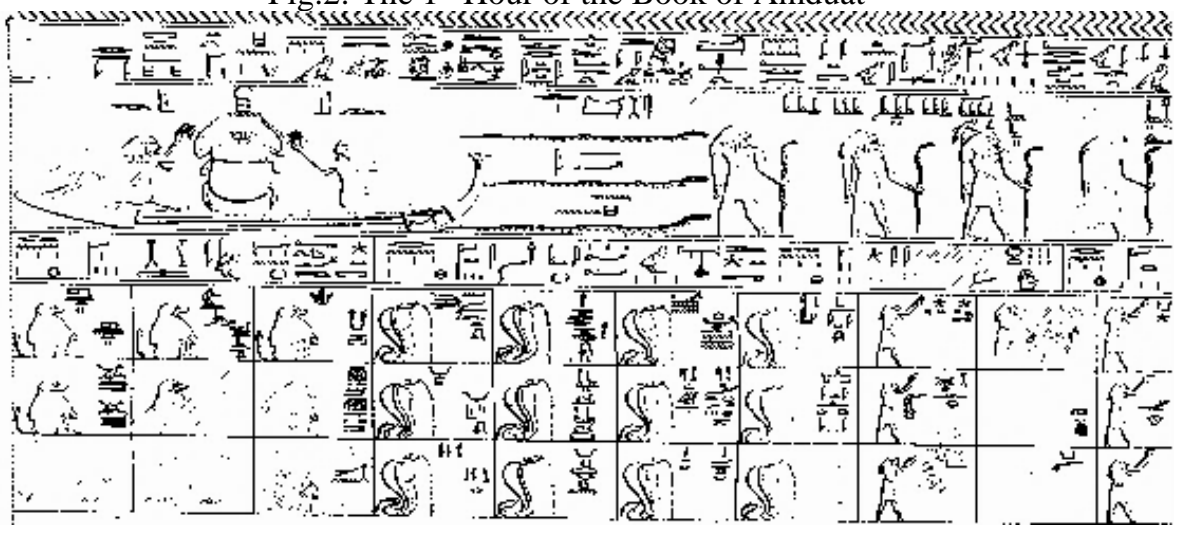

cf. Lefébure, G. (1884). Le Tombeau de Seti I, pl.xxv.

The $1^{\text {st }}$ hour consists mainly of three register the Upper register contain lists enumerating various important and typical being of the Netherworld, the middle register contains the main scene which represent the solar boat entering the western gate of the underworld (Hornung, 2007). The text reads as follow:

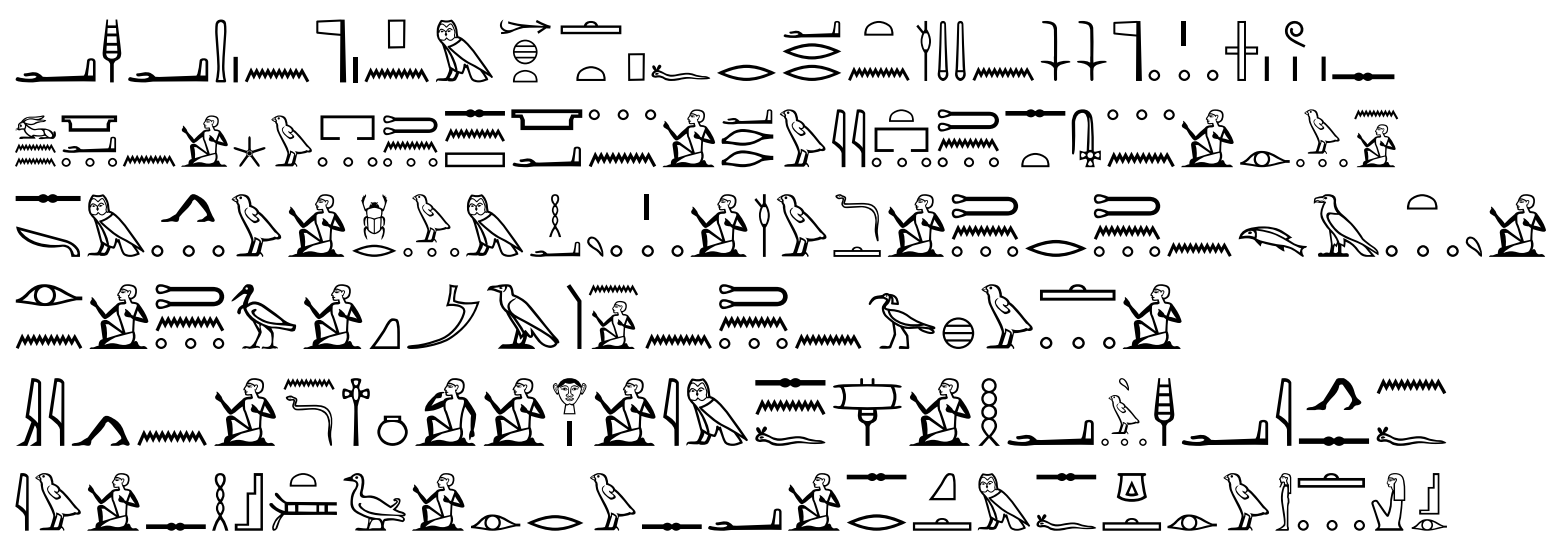




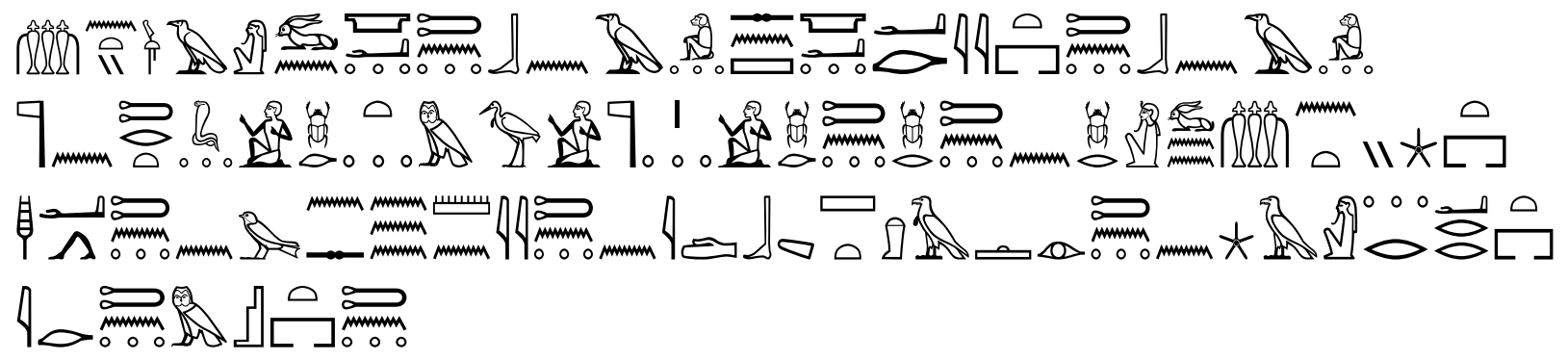

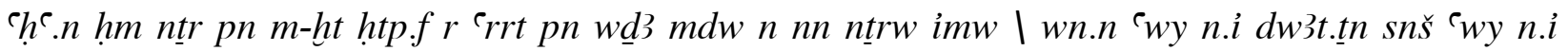

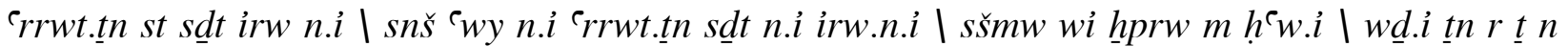

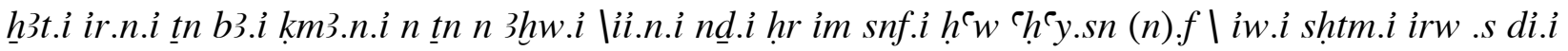
srk $m$ sfg irww (n) Wsir hnty -imntiw I wn 'wy.tn bntiw I snš 'wy 'rryt .tn bntiw ntrwt.i hprwt $m$

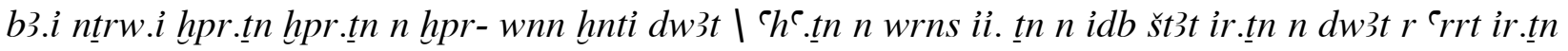
$m$ st. $\underline{t} n$

The majesty of this god raises up in his place, he transverses according to the commands of these gods, who are there, open the gate of your underworld for me, open the gateway for me to transverse them, to illuminate for me, they made for me, follow me to create my member, according to my command to them my corpse was made my soul, I created for them through my spirit, I come enquire about me there to breathe whether the members will raise up with them for him, my place in the hereafter. (Wb III, 198), they made it, I gave breath in the invisible form of Osiris (Wb.I, 113). The foremost of the underworld, open your gate for the baboons gods, open the gate for them, the baboons gods who created my soul, my goddesses since the creation existence, the foremost of the underworld, you raises up to Wernes (Osiris river), they comes to the river banks, they made the secret of the underworld, making them trans versing to their place.

In the Middle register (scene 1) represent the sun god in the form of god Khepri inside his solar boat enters the underworld and welcomed by the gods of the underworld and a representation of the creative of the underworld (Horunung,2007,.19). The text of the middle register under the scene of the procession of the solar boat read as follows (Bucher, 1931).

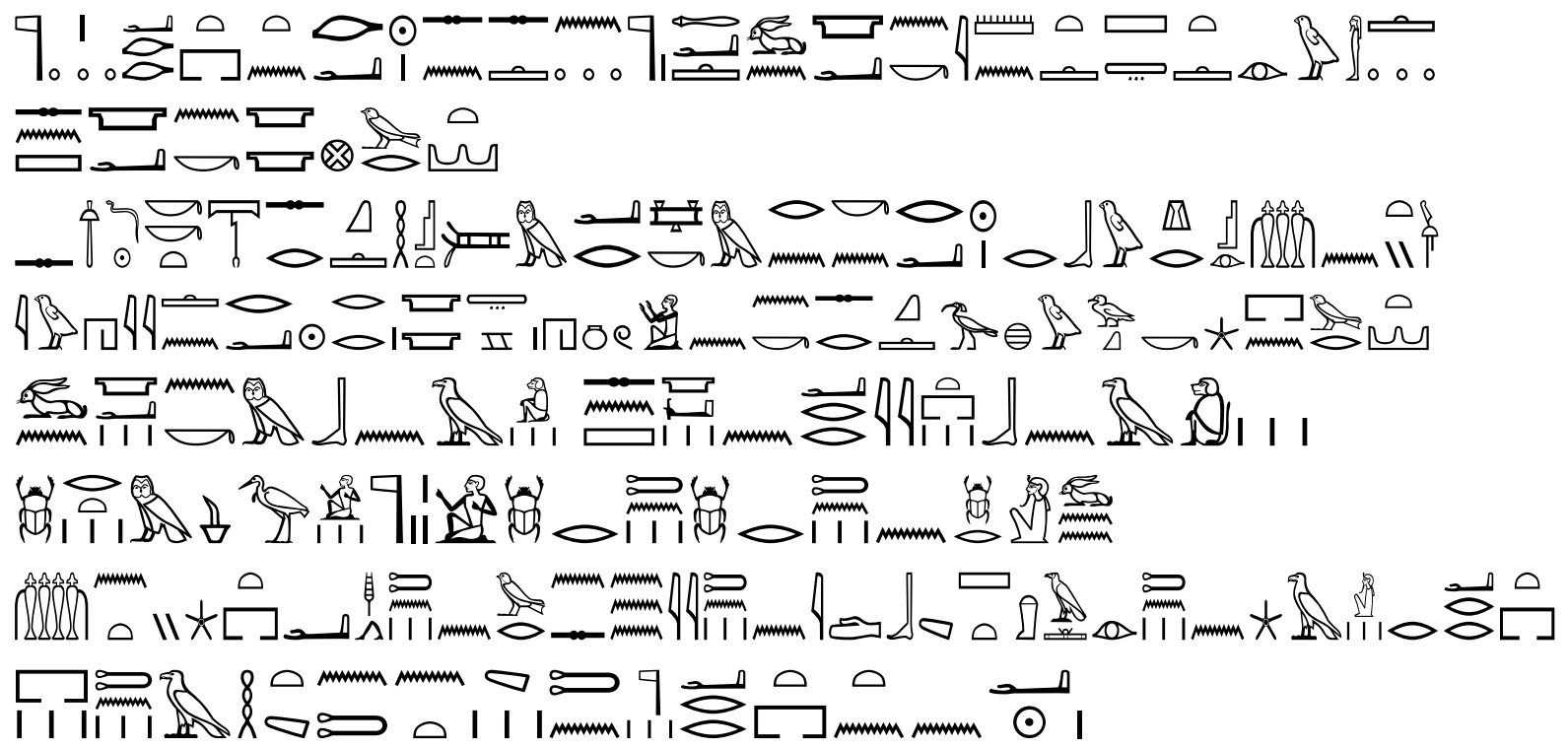




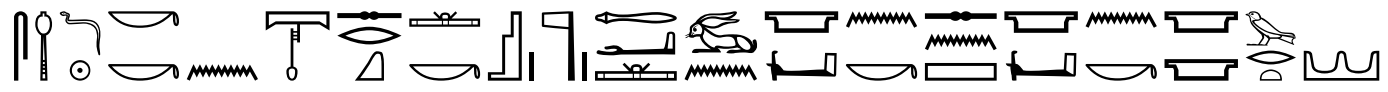

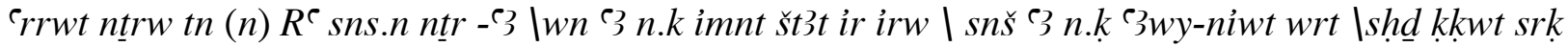

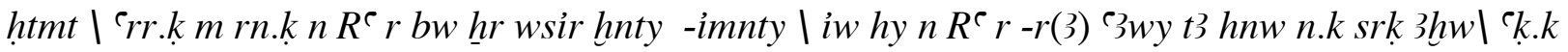

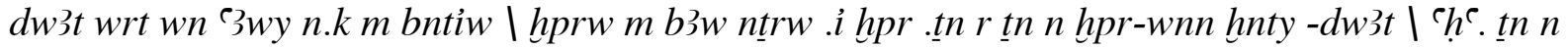

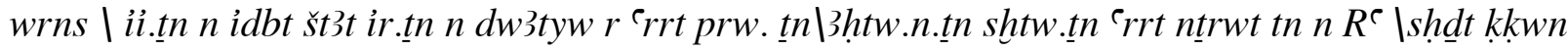

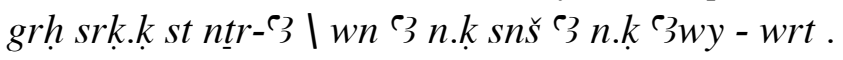

These gods transverse to Re, they praise $(\mathrm{Wb} \mathrm{IV,171)}$ the great god, open the gate of the underworld for me, the secret form of the underworld was done, open $(\mathrm{Wb}, 174)$ your gateway of the great city light the darkness, you make the place of the hereafter or Netherworld (Wb III,.198), breathe. you ascend in your name of Re to the place where Osiris, the foremost of the underworld, there be cries of joy for Re early in front of (Wb II, .389), the double door of the earth, acclaimed to you that the soul (Akh) breathe, when you enter the door of the great underworld, we open the double doors to you as baboons, created by my soul of my gods, created to them since the existence of the foremost underworld, they raise up to Wernes, they go to the river bank they made the secret of the underworld when they go to their houses they transverse to their domain, their fields, these goddesses ascend to Re to enlighten the darkness, you make the place breathe ,the great god open the gate for you open(Wb IV,.174) the gate way for you the great Jate.

\section{The $1^{\text {st }}$ division of the book of Gates}

The Initial division of the Book of Gates was depicted on the western wall of the inner part of the Burial chamber $(\mathrm{K})$ nearby the Sarcophagus (Lefebure,1884), The domain or field of this division is the western horizon mountain, the guardian god of the gate is god "smt" the guardian of the western horizon mountain (Piankoff \& Mystre, 1939)

Fig. 3: The $1^{\text {st }}$ division of the book of Gates divided into 3 register

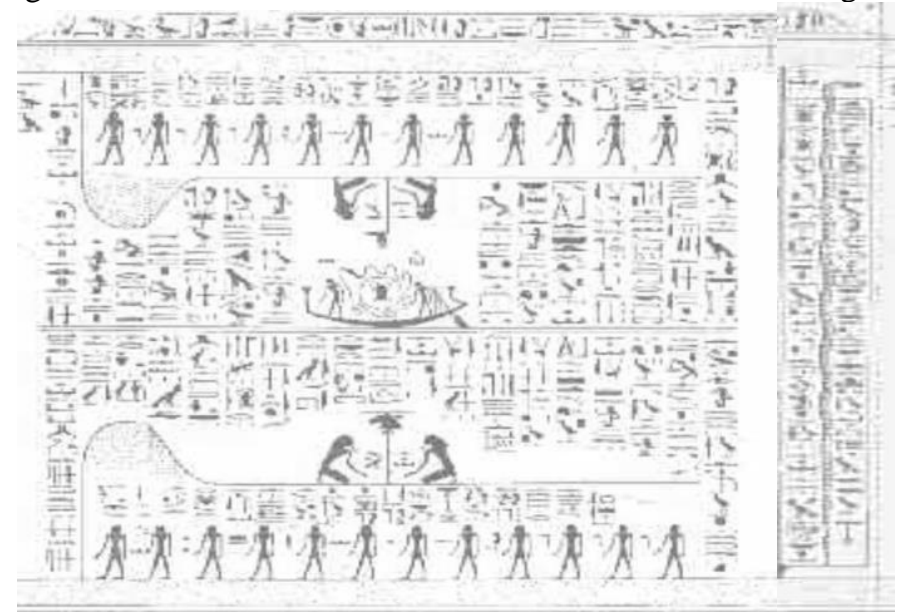

cf. Hornung, E. (2014) The Egyptian Book of Gates. Zurich.

The scenes of the first division of the Book of Gates consist of three register (Fig.2), in the Middle register (scene 2) the sun god approaches the Underworld and is greeted by "gods of the West", The sun god in the form of god Khepri surrounded by a snake god to protect him ,he travels with god Sia and god Hw (the personification of perception and spoken word. On the right part of the scene appears the mountains of the western horizon divided in two parts to allow the solar boat to sail into the underworld. Above the solar boat, there is a standard with a Jackal's 
head, below the solar boat there is a standard ended with symbol of god Atum -Re " Ram's horn headed" supported by symbol of the guardian god of the Western Horizon "smt. (Lefebure,1884; Hornung, 2014).

Accompanied the scene of the middle register (scene 2) texts above the solar boat of $\operatorname{Re}$ the epithet of the Western desert gods (Piankoff \& Mystre,1939; Hornung, 2014).

979 具 and below the figure of the Solar boat reads as follows:

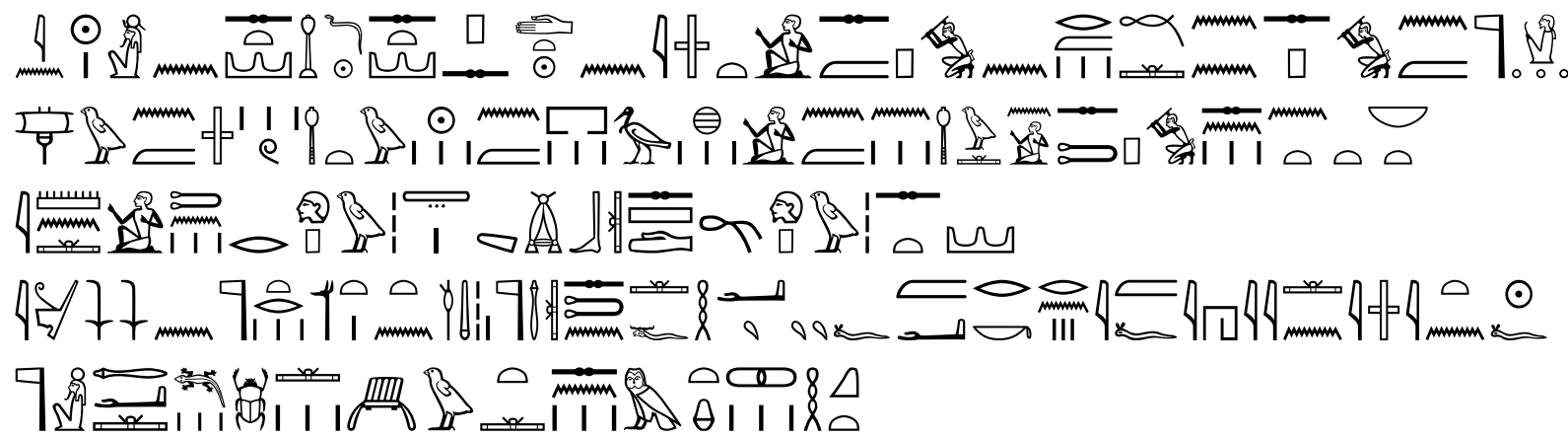

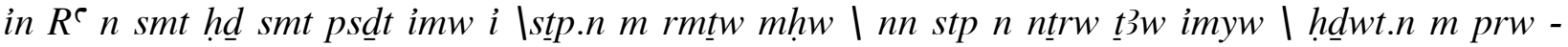
3hw.(i) $m \mid n h \underline{h} \underline{d} w$ n.i $\mid s \underline{t p}$. sn ntt nbt \imn.i tn $r$ tpw $t 3 \backslash \underline{d} b 3$ sšd tpyw smt $\backslash$ in nn $n$ wsrwt -ntrwt tn

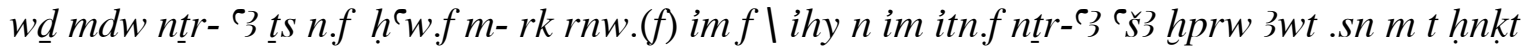

Re says to god "Smyt"(the Western mountain god) (Wb IV, 120) ,brighten "smyt",the Ennead (Wb.I,.559) among them I am, the works (Wb .II, 124) of humans have removed, the god will not remove whom are breathing there ( $\mathrm{Wb} . \mathrm{V}, 353)$, they will not remove anything there, hide me from them at the edge of the land Adoring while wearing the headdress (Wb $V$,.557) at the end of the desert, these powerful gods says according to the command of the great gods, collected to him his members (Wb.V, 400), by the name of him he is there, hail to him who is in his sun disc, the great god who has various creative, their sacrificial food consist of bread and beer.

\section{Discussion about relation between scene 1 and text $1^{\text {st }}$ hour Amduat and scene 2 and text of $1^{\text {st }}$ division book of Gates}

When it was compared between the scene of the middle register (scene 1) Amduat and (scene 2) Book of Gates, the scene of middle register $1^{\text {st }}$ hour Amduat describes the procession of the solar boat,whereas, the sun god is represented in the form of god Khepri in the middle of the boat surrounded by guardian gods to protect him, while in the middle register of the $1^{\text {st }}$ division Book of Gates, it depicts the Western Horizon Mountain divided into two parts through which the solar boat pass

the guardian god of the $1^{\text {st }}$ hour Amduat was mentioned in text but the Guardian god who will facilitate and overcome dangerous spirit when the sun god and the soul of the deceased enters the gate of the underworld was represented in figure and text god "smt" the guardian god of the Western Horizon Mountain, he opens the gateway for the solar boat procession.

This statement agreed with the statement of (Sadek, 1985) that the first 8 hour of the Amduat without illustration comprising funerary theme for the deceased king can be summarized that. it was used as a guide for the soul of the king in the procession of the navigator's solar god boat.

Meanwhile the scene 2 of the book of Gate depicts the danger encounter the soul of the deceased king while entering the underworld and how to overcome it. this is also indicated from the accompanied text; it describes the Solar boat procession when enters the Gate of the underworld 
'rrwt ntrw th (n) R` sns.n ntr - 3 |wn 93 n.k imnt št $3 t$ ir irw

These gods transverse to Re, they adore the great god, open the gate of the underworld for you the secrets of the Underworld has made

The text of the middle register (scene 2) of book of Gates describing the danger which will encounter the solar boat while entering the underworld and how to overcome it by the Guardian god of the $1^{\text {st }}$ gate, when Re call God smyt" to open the gate.

in $R^{\top} n$ smt had smt psdt imw.i.

Re says to god "smt" (the Western mountain god), brighten (smt), the Ennead among them I am, The common context between $1^{\text {st }}$ hour Amduat and $1^{\text {st }}$ division book of Gates is proved from the text of the upper register of the $1^{\text {st }}$ hour Amduat when god Re call the underworld gods to protect the mummy of the deceased and to collect his members.

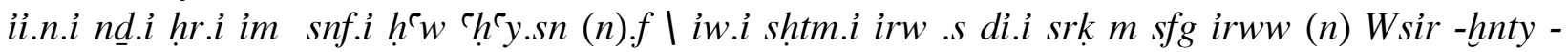
imntyw

I come enquire about me there to breathe whether the members will raise up with them for him, my place in the hereafter they made it ,I gave breath to the invisible form of Osiris

Similar context was mentioned in the middle register (scene 1) Amduat.

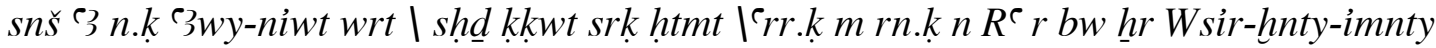

open your gateway of the great city light the darkness, you make the place of the hereafter breathe, you ascend in your name of Re to the place where Osiris, the foremost of the underworld.

in the middle register (scene 2 ), $1^{\text {st }}$ division book of gates the same context

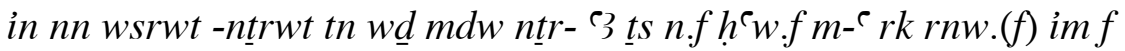

these powerful gods say according to the command of the great gods, collected to him his members, by the name of him he is there

\section{The $2^{\text {nd }}$ Hour of Amduat}

The scenes of the $2^{\text {nd }}$ hour of Amduat were depicted on the Western wall of the inner part of the burial chamber $(\mathrm{K})$, during the $2^{\text {nd }}$ Hour the Solar Boat sails through a river called "Wrns "the water of god Osiris (Fig 3) (Lefebure, 1884; Hornung, 2007).

Fig.3: The $2^{\text {nd }}$ Hour Amduat consist of 3 register.

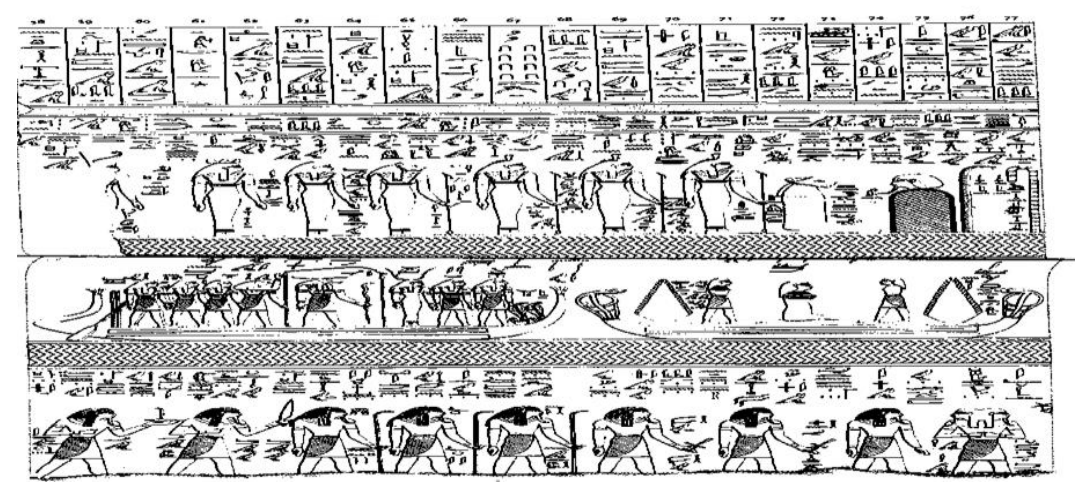

cf. Lefébure, G. (1884). Le Tombeau de Seti I, part IV, pl. xi

(Fig.3)

The $2^{\text {nd }}$ hour of Amduat consist of three register, the main scene of the middle register (scene 4) depicts the Solar boat trans versing the Watery river of god Osiris (fig.3) (Hornung, 2007). 
The sun god in the form of god Atum-Re appeared inside his Cabin in the middle of the boat beside him the Serpent goddess "Mhn" to protect him accompanied the sun god in his Solar boat a group of 8 gods and goddesses (George, 1972).

The text in the middle register accompanied the scene of the Solar boat read as follows: (Bucher, 1931)

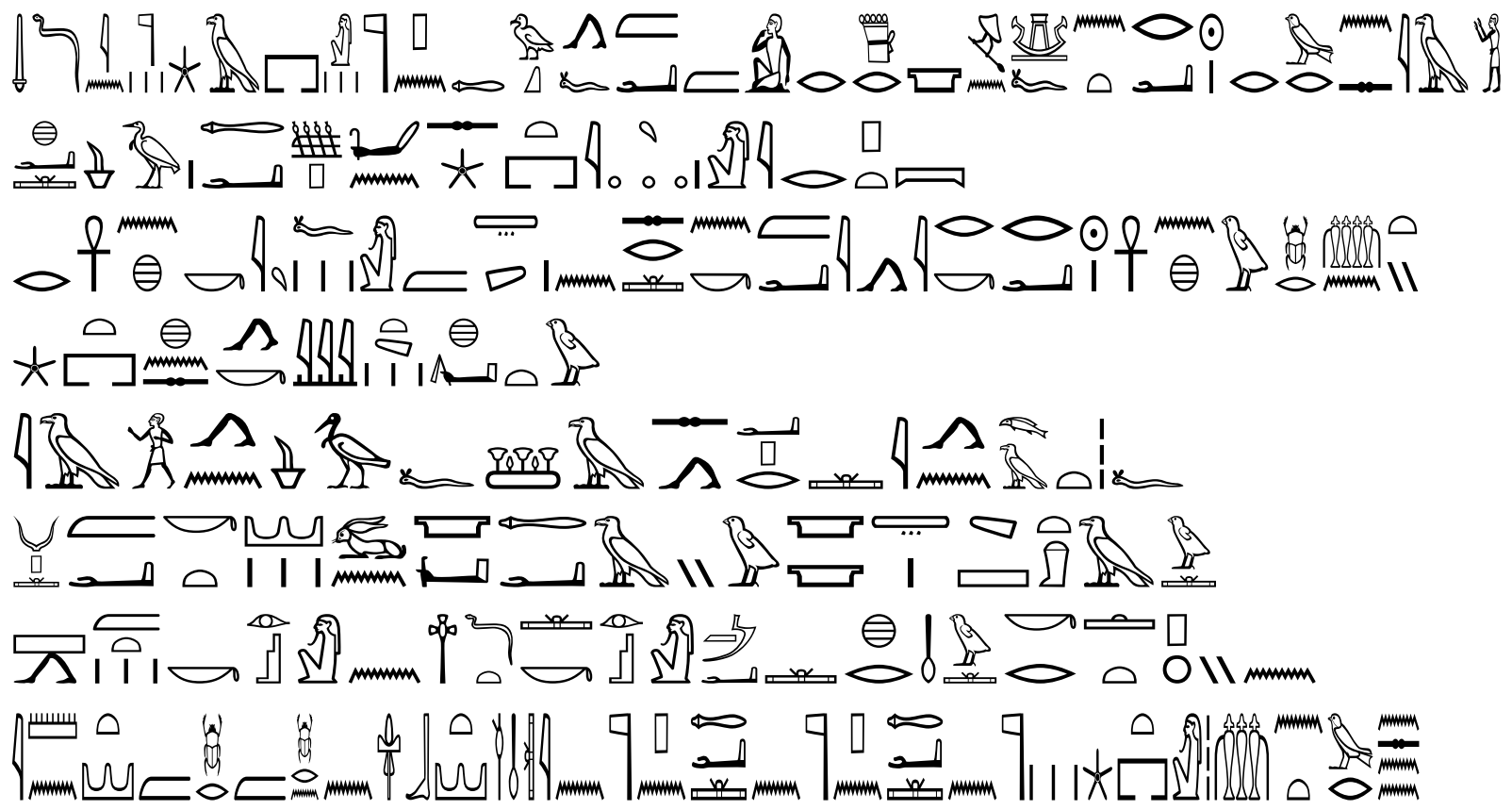

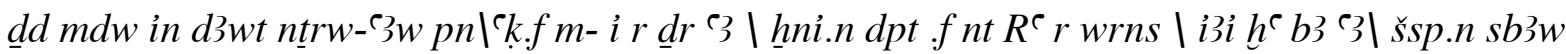

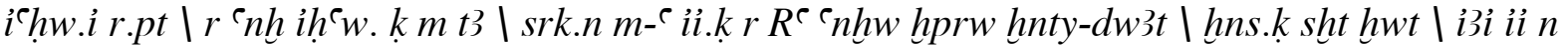

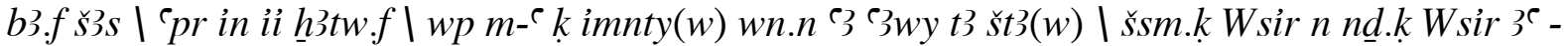

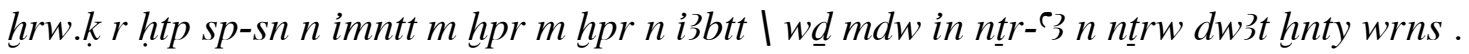

Speech of the great gods of the underworld, He come in with me to the edge of the Gate, he sails in his boat of Re to Wernes (Osiris river), adore the great shining soul, receive on the doors of the gate my flesh, body.(Wb.III, 38), ascend to sky, live to your flesh on the earth, you breathed (Wb IV, 204) you come with Re to the living creative created since existence of the underworld, he traverse the distributed fields (Wb I, 229) adoring his missing coming soul (Wb IV, 413) trans versing with his coming corpse, open with you the great gate of the underworld of the secret land, they follow you Osiris to protect you Osiris you are the true voice to be offered 2 times in the underworld which was created in the East according to the command of the great gods of the underworld which is upon the Wernes (Osiris river).

The $2^{\text {nd }}$ hour Amduat describes the creative on both banks of the river of god Osiris while the Solar boat of Re trans versing the river. (Darnell, 2004). According to Hornung (1963 and 1987) in the darkness, the sun god cannot see the creative and must therefore be guided to them by their voices.

\section{The $2^{\text {nd }}$ division of the Book of Gates}

The scenes of the $2^{\text {nd }}$ division of the Book of Gates were depicted on the eastern wall of the inner part of the burial chamber $(\mathrm{K})$. The guardian goddess of the $2^{\text {nd }}$ gate took the form of a serpent 
goddess called ( $3 k b y$ ), the domain or field of the $2^{\text {nd }}$ division is watery river which is called "Wrns" the water of god Osiris.

The $2^{\text {nd }}$ division is divided into 3 register (Hornung, 2014), the scene of the Middle register (scene.5) represents the sun God in the form of a Ram headed god Atum-Re is towed by four men to the river bank accompanied by two gods Sia and Hw, god " $h k 3$ " who personify the magic accompanied the sun god in his boat (Lefebure, 1884) (Fig.4).

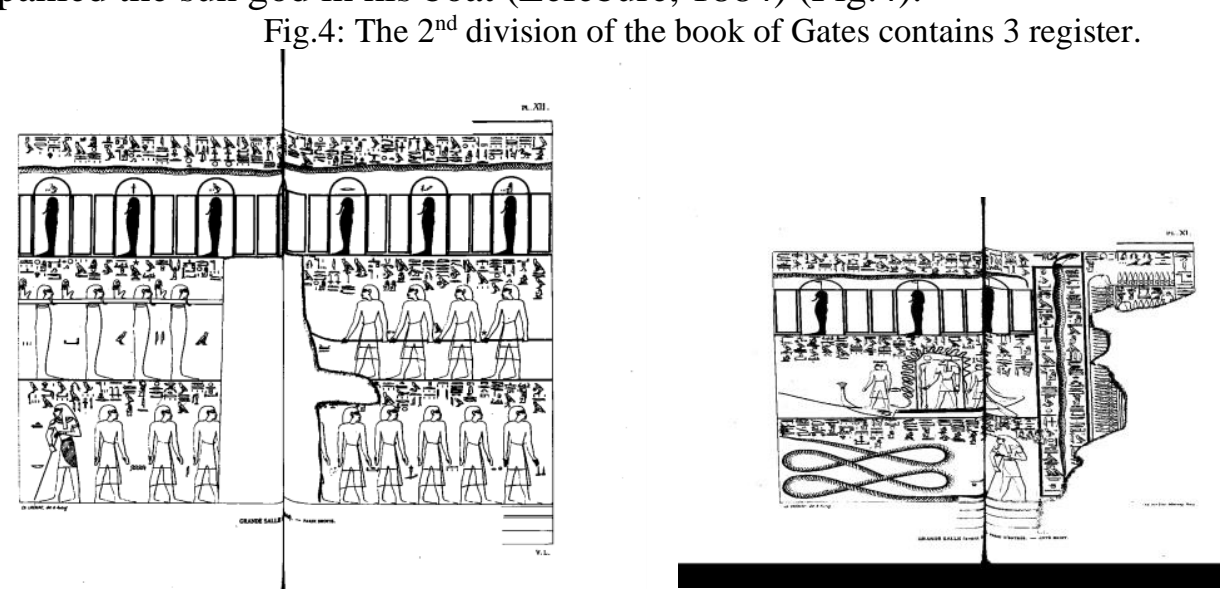

cf. Lefébure, G. Le tombeau de Seti I .part IV, pl. xi-xii.

The Text in the Middle register accompanied the scene of the Solar boat read as follow: (Lefebure, 1884; Hornung, 2007).

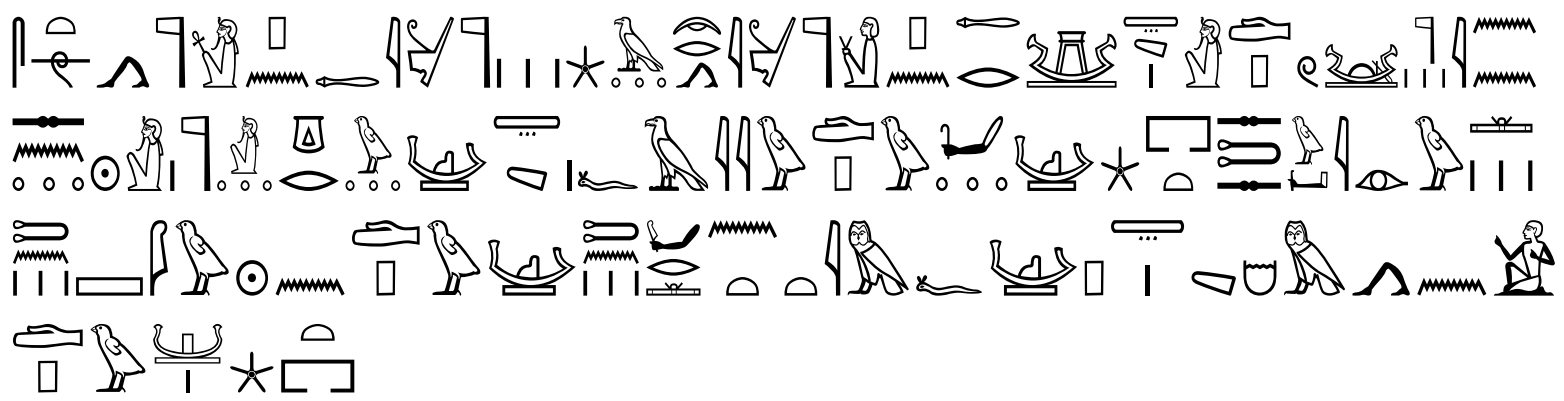

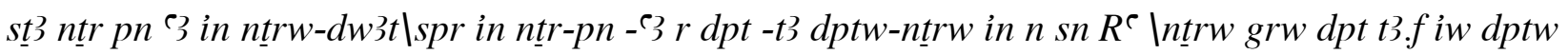

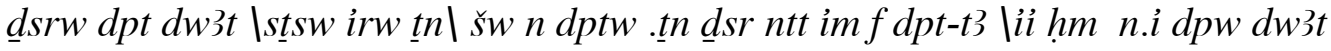

the great god draw (Wb IV, 352) by the underworld gods, this god arrive to the land of sailing, the gods boats belongs to Re, moreover the gods sails in his land. The stronger boat is of the underworld, they support their form (Wb I, 113), the sun light in their stronger boat similar to his which is there on the land of sailing, his majesty came to me through the Underworld boats.

\section{Discussion about relation between the $2^{\text {nd }}$ hour Amduat and the $2^{\text {nd }}$ division book of Gates}

When it was compared between the scene of the middle register of (scene 4) Amduat and (scene 5 ) book of gates the scene of middle register $2^{\text {nd }}$ hour Amduat (scene 4) describes the procession of the Solar god boat while trans versing the river of Osiris which was called Wernes the sun god is represented in the form of god Atum-Re beside him in the middle of the boat the Serpent goddess " $M h n$ "to protect him, accompanied the sun god in his solar boat a group of 8 gods. Otherwise the main theme of the middle register scene of the $1^{\text {st }}$ division of the book of gates (scene 5) depicts the same theme of the Solar boat of Re while trans versing the watery river of Osiris, the sun god in the form of a Ram headed god Atum-Re is towed by four men to the river 
bank and accompanied by 2 gods Sia and Hw, god $h k 3$ who personify the Magic accompanied the sun god in his boat (George, 1972).so it obvious the similarity in the main theme of both scenes and this is appeared also from the text accompanied both scenes.

The text accompanied the middle register of the $2^{\text {nd }}$ hour Amduat (scene 4 ) indicate that the soul of the deceased sail with the sun god through Osiris river and the deceased asked from god Re to receive his soul on the gateway and to give his soul live.

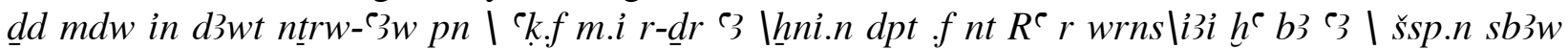

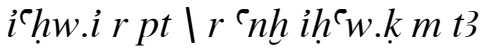

Speech of the great gods of the underworld, he come in with me to the edge of the gate, he sails in his boat of Re to Wernes (Osiris river), adore the great shining soul, receive on the doors of the gate my body, ascend to sky, live to your body on the earth.

The text accompanied (scene 5) of the middle register of the $1^{\text {st }}$ division of the book of Gates mentioned that god Re call up the guardian gods of the riverbank Wernes and asked from them to protect his boat when he arrives to that area.

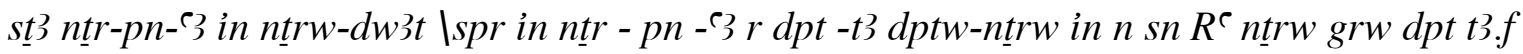
the great god draw by the underworld gods this god arrive to the land of sailing, the gods boats belongs to Re, moreover the gods sails in his land.

\section{The Third hour of Amduat}

The third hour of the Book of Amduat was depicted on the Eastern wall of the Burial chamber $(\mathrm{J})$ and it consist of 3 register, the Middle register (scene.7) represent the solar boat complete trans versing the watery river which called wrns, the water of Osiris (fig.5) (Lefebure, 1884; Hornung, 2007).

Fig.5: The $3^{\text {rd }}$ hour of Amduat divided into 3 register

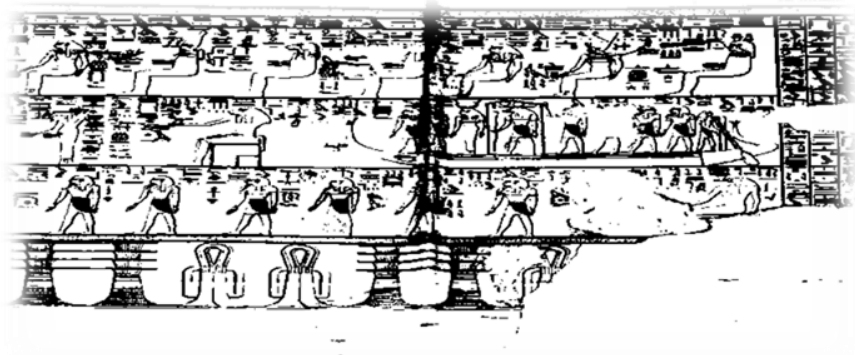

cf. Lefébure, G. (1884). Le Tombeau de Seti IV, pl. xxxi.

The text accompanied the solar boat reads as follow (Bucher,1931,.242).

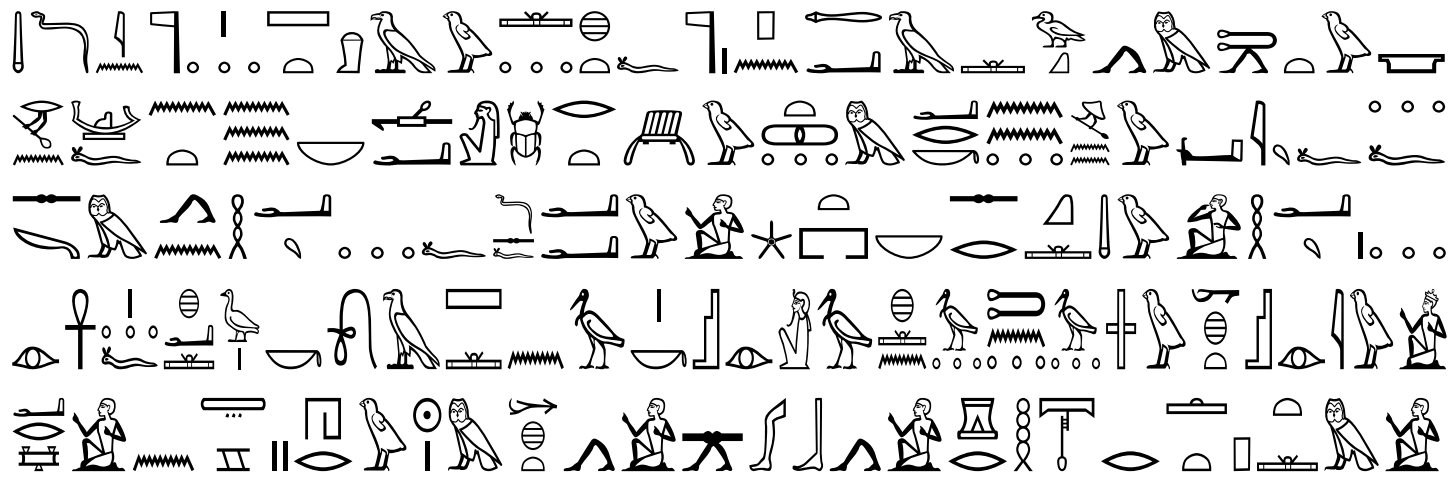




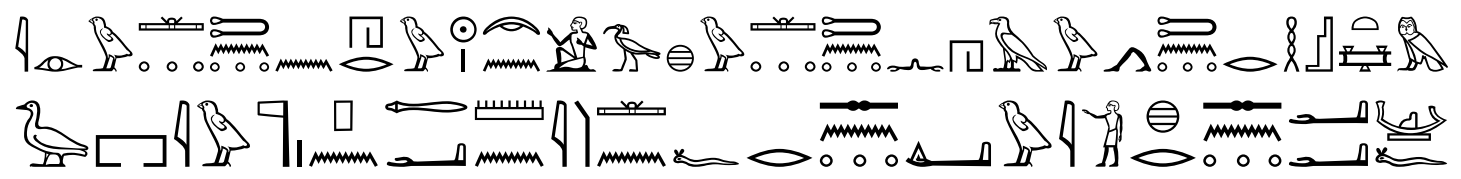

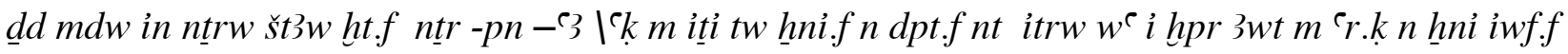

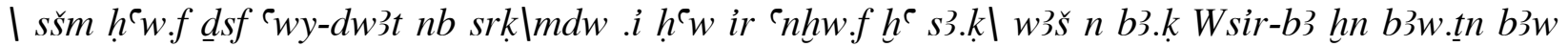

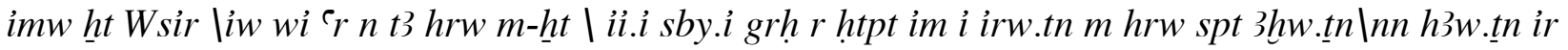
htm s3-prliw ntr-e3 mni.f r sn di.tw i3i hr sn 'wy dpwt.f

Speech of the secrets of the gods possessed by this great god, he comes seizing, he sails in his boat of the river, while I am the only one (Wb I, 274) offering during his transverse during sailing his flesh (Wb I, 51) followed by his member catching( $\mathrm{Wb} \mathrm{V,} \mathrm{486)} \mathrm{with} \mathrm{my} \mathrm{two} \mathrm{hands} \mathrm{the}$ underworld, $O$, lord of breathing, my words that the body, he will give life to the shinning son be stronger is your soul, the soul of Osiris through their soul following Osiris ,I come on to the earth during daylight, I passed the night offering there ( $\mathrm{Wb} . \mathrm{V}, 184)$ they will do the same thing at the end of the daylight, their spirit will not hurt in the afterlife, the son of the house, whereas the great god make them to die (Wb.II, 76) pray to catch his boat by his two hands.

\section{The $3^{\text {rd }}$ division of the Book of Gates.}

The scenes of the $3^{\text {rd }}$ division of the Book of Gates were depicted on the left wall of the annexed room (L) right to the burial chamber (Lefebure, 1884). The domain or field of the $3^{\text {rd }}$ division is watery river which is called Wrns. The water of Osiris, the guardian goddess of the gate took the form of a serpent called $\underline{d}$ tby. (Hornung, 2014).

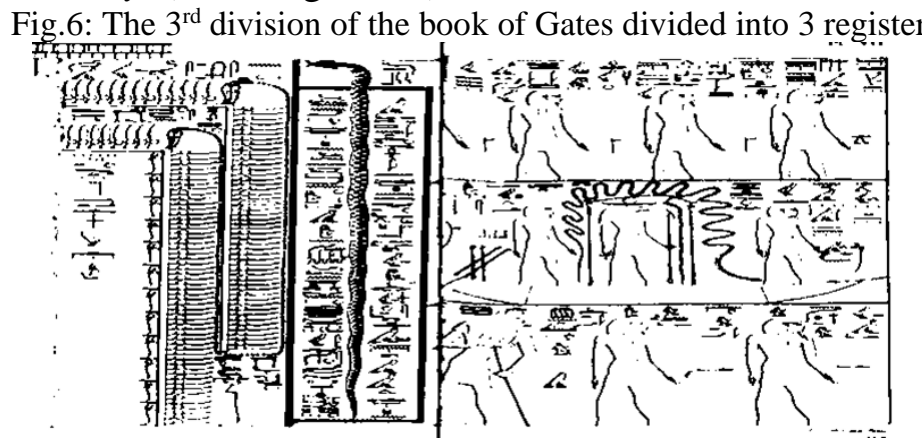

cf. Lefébure, G. (1884). Le Tombeau de Seti I .IV,Pl.vii

the Middle register of the $3^{\text {rd }}$ division (scene.8) represent the Solar boat is towed by four Men, the sun god is accompanied by 2 gods Sia and god " $h w$ " the cord pulling the Solar boat is attached to a long pole with a Bull's head at each end (Hornung, 2014). The text in the middle register accompanied the scene of the Solar boat read as follow: (Piankoff \& Mystre, 1944)

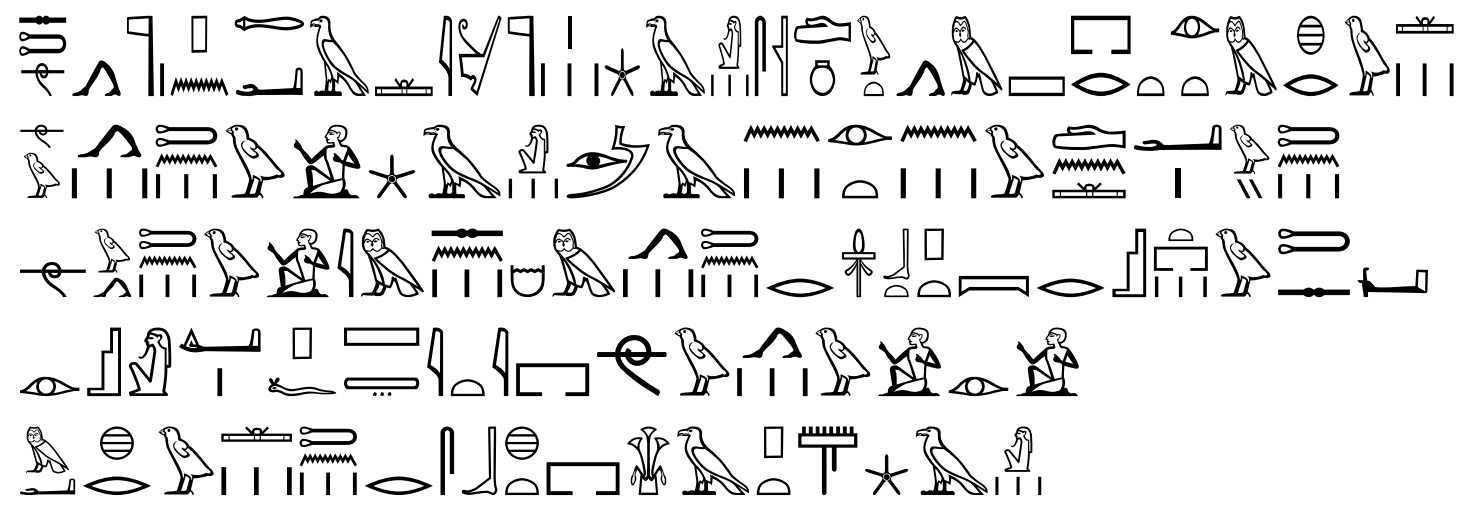




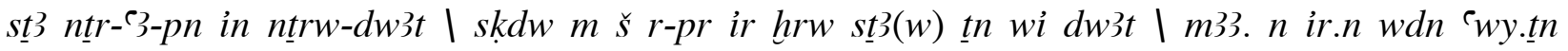

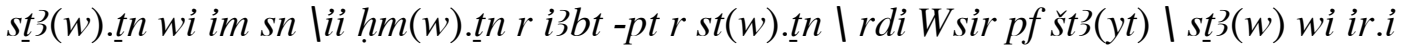

$m 3^{C}-h r w . t n r$ sbht ḩ3y dw3t.

the great god pull me to the underworld gods, the youthful sailors to the chapel, making voice, they pull me to the underworld, they decided to install their arms to drag me to them there, their majesty arrive to the eastern sky to their places Osiris provide the mysterious, they pull me , I made them true -voiced to (go to) the Sanctuary of Osiris (Wb.IV,.92), the early morning: (Wb.V,.423) in the Underworld .

\section{Discussion about relation between the $3^{\text {rd }}$ hour Amduat and the $3^{\text {rd }}$ division book of Gates}

When it was compared between the scene of the middle register of (scene 7) Amduat and (scene 8) Book of Gates, the scene of middle register $3^{\text {nd }}$ hour Amduat describes the procession of the solar god boat complete traversing the river of Osiris which was called Wernes the sun god is represented in the form of god Atum-Re, while the Middle register of the $3^{\text {rd }}$ division Book of Gates (scene.8) represent, the solar boat is towed by four men, the sun god in the form of god Atum-Re accompanied by gods Sia and Hw. The cord pulling the Solar boat is attached to a long pole with a Bull's head at each end, so it obvious the similarity in the main theme of both scenes and this is appeared also from the text accompanied the middle register (scene 7) it is describing the sun god while sailing trans versing the watery river (Wernes)

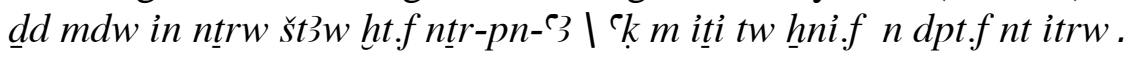

Speech of the secrets of the gods possessed by this great god,he comes seizing, he sails in his boat of the river.

The text accompanied (scene 8) $3^{\text {rd }}$ division book of gates indicate that the sun god asked from the underworld guardians gods of the river Wernes to help the soul of the deceased to traverse the watery river.

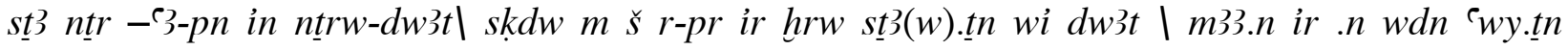
st $3(w) . t n$ wi im sn

the great god pull me to the underworld gods the youthful sailors to the chapel making voice, they pull me to the underworld, they decided to install their arms to drag me to them there.

The $4^{\text {th }}$ hour of the book of Amduat.

The scenes of the $4^{\text {th }}$ hour of the book of Amduat depicted on the right wall of the $3^{\text {rd }}$ Corridor (C) of the Tomb of Seti I at the first main qxe of the tomb (Lefebure, 1884).

Fig.7: The $4^{\text {th }}$ hour of Amduat divided into 3 registers.

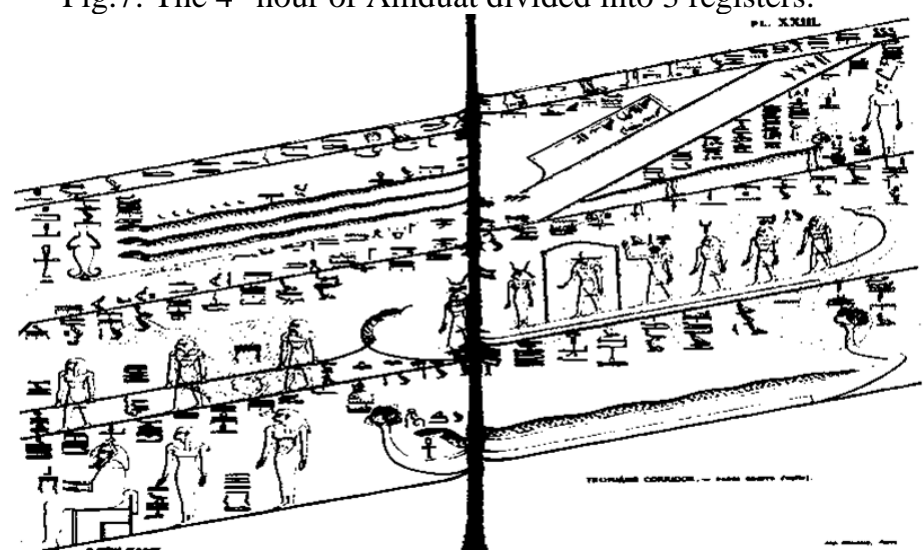

cf. Lefébure, G. (1884). Le Tombeau de Seti I. part. I, pl. xxiii.

The scene of the Middle register represents (scene.10) the Solar boat of Re accompanied by the soul of the deceased reaches a region called "imht" a difficult sandy area of Sokar the god of the 
Necropolis, where he passes through a difficult pathway so he is being dragged on a ledge, its prow take a form of a snake (Fig.7) (Hornung, 1999).

Darnell stated that there are two way the solar boat of Re must pass through during the $4^{\text {th }}$ hour the first way was called "imht" the path on water and the second path was called " $d 3 t$ " that on land called "imht" is however a portion of the realm of god Sokar. Otherwise, it was mentioned in the Coffin Text Spell (CT.§1068) as a part of the underworld (Darnell, 1995).

The text accompanied the Middle register read as follows:

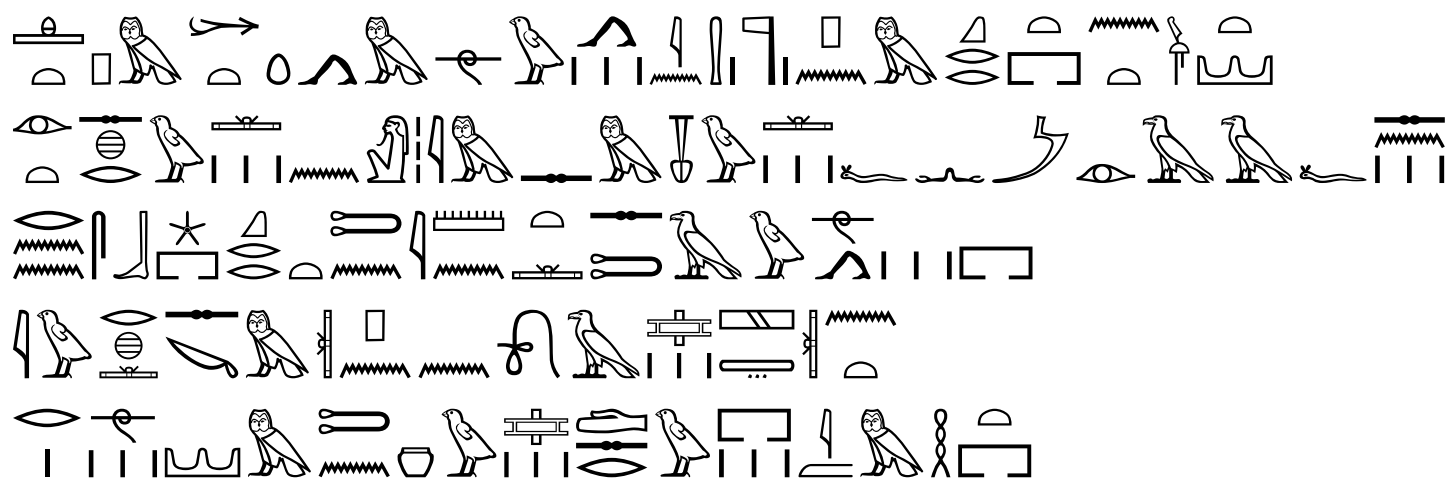

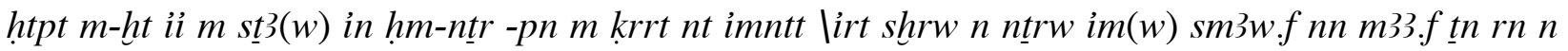

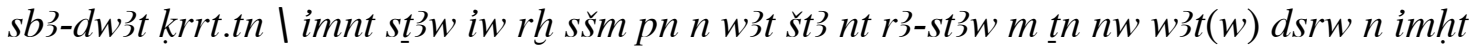

Offering after arriving pulling the majesty of this god to the Necropolis of the underworld, do as the advice of the gods there, he will equalize when he does not see them know the name of the gateway of the underworld the hidden mysterious, to know this guide to the mysterious road of the Region Restaou (Wb.II, 393) with you of the roads of Deserou of the Region (Imhet) (Wb.I,.88).

\section{The fourth division of the Book of Gates}

The scenes of the $4^{\text {th }}$ division of the Book of Gates were depicted of the 4 pillared hall (E) of the first Axe of the tomb, the Gate of the 4 division was guarded by a god whom took the form of a Snake called "th 3 - $h r$ " (Lefebure, 1884; Hornung, 2014).

Fig .8: The $4^{\text {th }}$ division of the book of Gates divided into 3 registers.

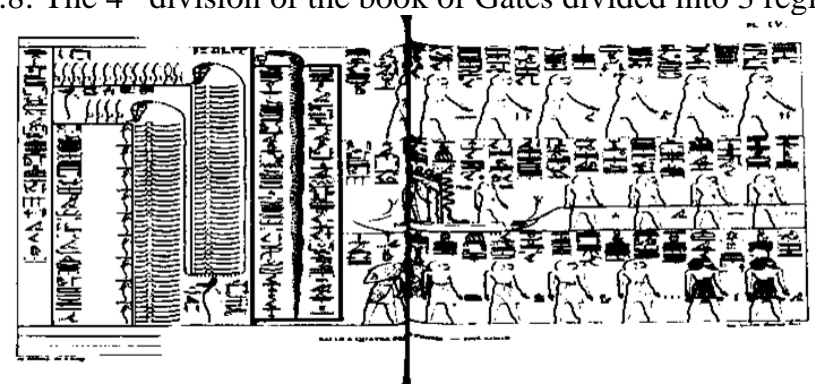

cf. Lefébure, G. (1884). Le Tombeau de Seti I. part II, pl. iv

The $4^{\text {th }}$ division of the book of Gate divided into 3 register the main scene of the middle register (scene 11) represent the Solar boat is towed towards 9 Shrines containing Mummified gods they named the gods who follow Osiris to the tomb of Sokar. They wait for sun god to be resurrected and feed them. (Fig.8) (Hornung, 2014). the text accompanied the solar boat middle register reads as follows (Piankoff \& Mystre, 1944).

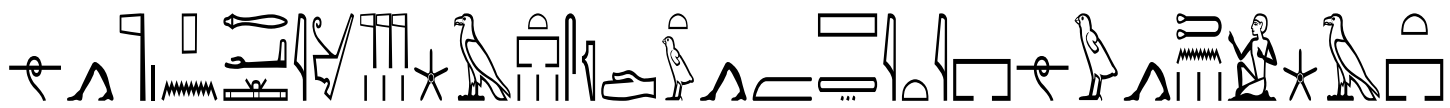




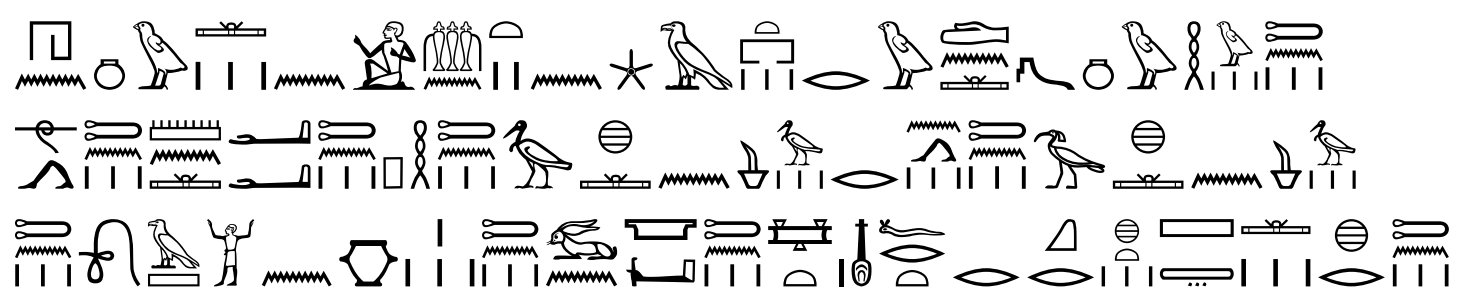

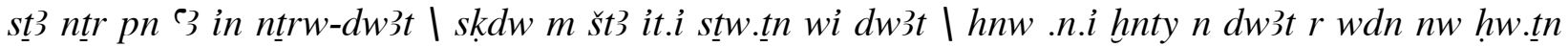

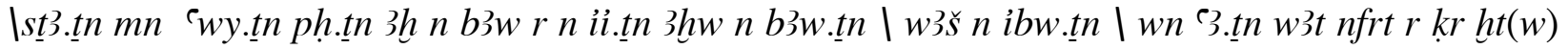
$\breve{s} t 3 \mathrm{hr} \underline{t} n$.

draw this great god to the underworld god, sailing with mysterious in my sovereignty, they draw me to the underworld they praise inside the underworld, to the unknown at the proper time they proclaim, they draw with fixed hands their spirit reached their souls, their spirit comes to their souls, be stronger their heart, open their good gate pathway which have more bend, the mysterious is behind them.

\section{Discussion about relation between the $4^{\text {th }}$ hour Amduat and the $4^{\text {th }}$ division book of Gates}

When it was compared between the scene of the middle register of (scene 10) Amduat and (scene 11) Book of Gates, from the scene of middle register $4^{\text {nd }}$ hour Amduat describes the solar boat of Re accompanied by the soul of the deceased reaches a region called imht a difficult Sandy area of god Sokar (the god of the Necropolis), while the middle register scene of the book of Gates (scene 11) represent the solar boat of Re is towed towards 9 shrines containing mummified gods they named "the gods who follow Osiris".

The text accompanied (scene 10) of the $4^{\text {th }}$ hour Amduat describe the difficult sandy pathway through which the solar boat of Re path through.

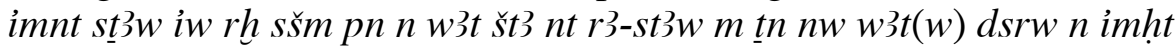

the hidden mysterious to know this guide to the mysterious road of the (Region Restaou) (Wb.II, .393)'with you of the roads of (Deserou) of the Region Imhet.

The text accompanied middle register (scene 11) of the $4^{\text {th }}$ division book of Gates mentioned that god Re appeal the guardian gods on his pathway of the Necropolis to open the pathway gate.

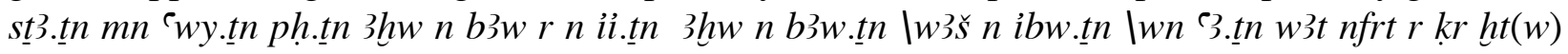
$\check{s} t$ ? $h r \underline{t} n$

they draw with fixed hands their spirit reached their souls, their spirit comes to their souls, be stronger their heart, open their good gate pathway which have more bend, the mysterious is behind them.

The $5^{\text {th }}$ Hour of the Book of Amduat

The scenes of the $5^{\text {th }}$ hour of the Book of Amduat was depicted on the left wall of the $3^{\text {rd }}$ corridor (C) of the tomb (Lefebure, 1884).

Fig .9: The $5^{\text {th }}$ Hour of Amduat divided into 3 Register.

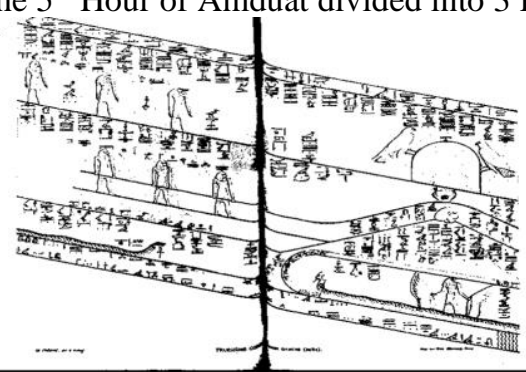

cf. Lefébure, G. (1884). Le Tombeau de Seti I, part I, pl.xxvii. 
The scenes of the $5^{\text {th }}$ hour of Amduat are divided into 3 register the scene of the Middle register (Scene 13) depicts the Hill were the Tomb of god Sokar-Osiris, whereas goddesses Isis and Nephtys appear upon the Hill, while a group of men pulling the Solar boat of Re to reach the hill. (Hornung, 2007).

The text accompanied the scene of the Solar boat reads as follows (Hornung, 2007).

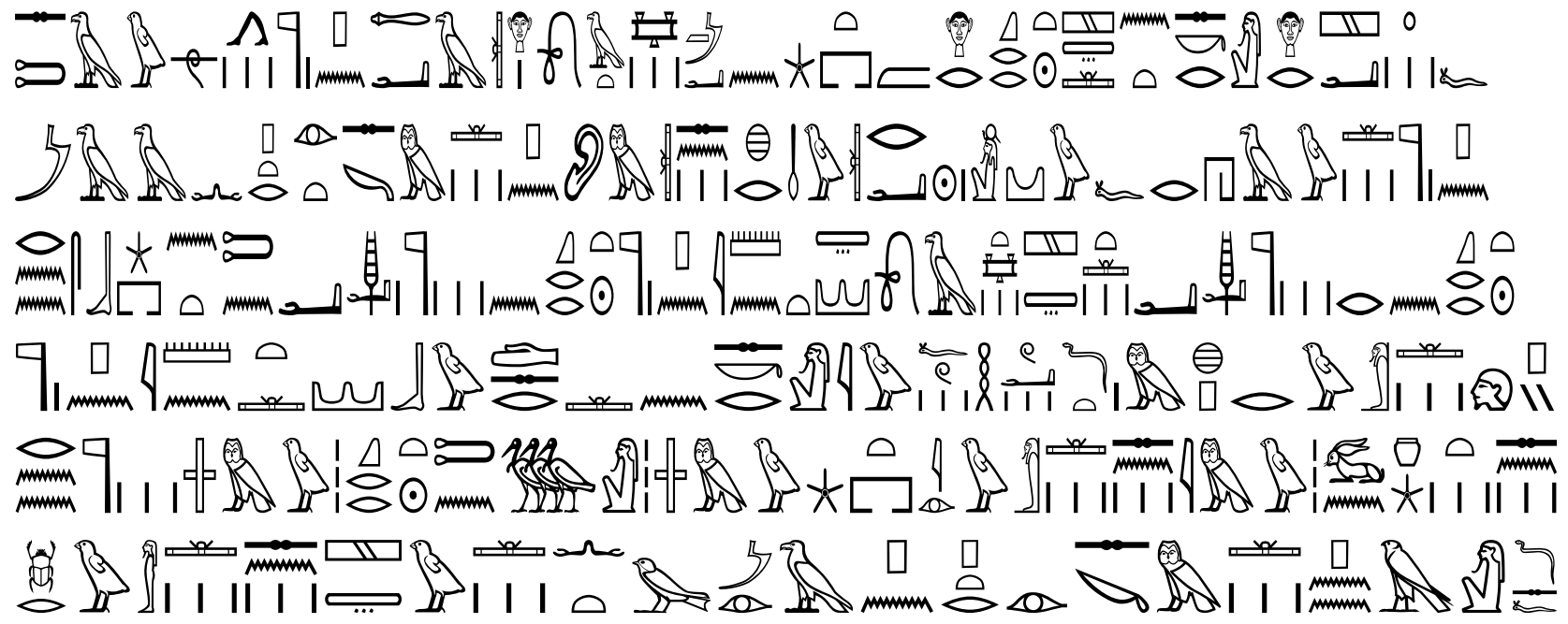

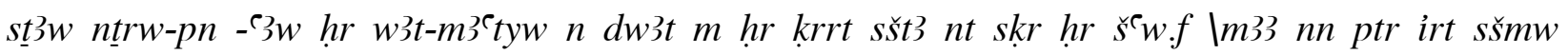

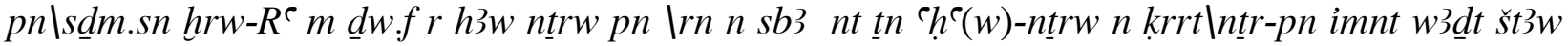

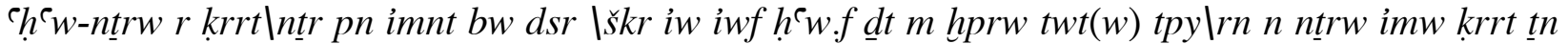

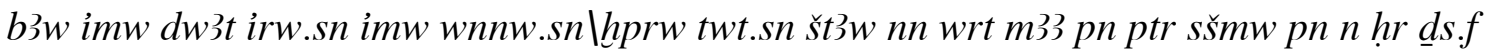

the great god is towed on the paths of Maat of the underworld upon the mysterious tomb of Sokar upon his sand, which has no view.(Wb.I, 564) to follow that, they hear the voice of Re upon his hill to be nearby these gods, the name of your gateway is the residence of the god to the necropolis , this the hidden way where the gods raise up to the necropolis, this god is hidden by himself, god Sokar whose his flesh and his members is forever a created form typically (Wb.V, 276), the name of the gods on your cavern (tomb) is Ba souls who are in the underworld, their shape which are in their hour, their creative shape is unknown, unseen and unperceived is this image (Wb V, 256) of Horus himself

\section{The Fifth division of the Book of Gates}

The scenes of the $5^{\text {th }}$ division of the Book of Gates were depicted on the 4 pillared hall (E) at the beginning of the Second Axe of the tomb (Lefebure,1884). The domain of the field of the $5^{\text {th }}$ division is the Necropolis where god Osiris is buried. The guardian god of this gate is snake god called "s $\underline{d}$ t-ir.f " extruder fire" to protect the Entrance of the Gate from the evil serpent Зpp(Hornung, 2014)

Fig.10: The $5^{\text {th }}$ Division of Book of the Gates divided into 3 Registers.

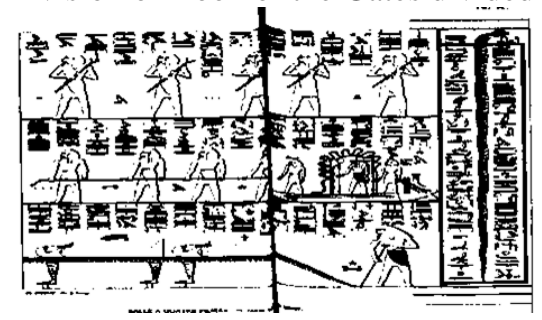

cf. Lefébure, G. Le Tombeau de Seti I, part II, pl.x. 
The scenes of the $5^{\text {th }}$ division of the book of Gate divided into three register, the Middle register (scene 14) represent the Solar boat of god Re accompanied by two gods " $h w$ and Sia".in front of the Solar boat stand four gods towing the Solar boat 12 gods holding the coils to cripples the movement of evil serpent $3 p p$, they are named as "those who catch the snake 3pp (Hornung, 2014).

The text accompanied the Middle register reads as follows (Piankoff \& Mystre, 1944).

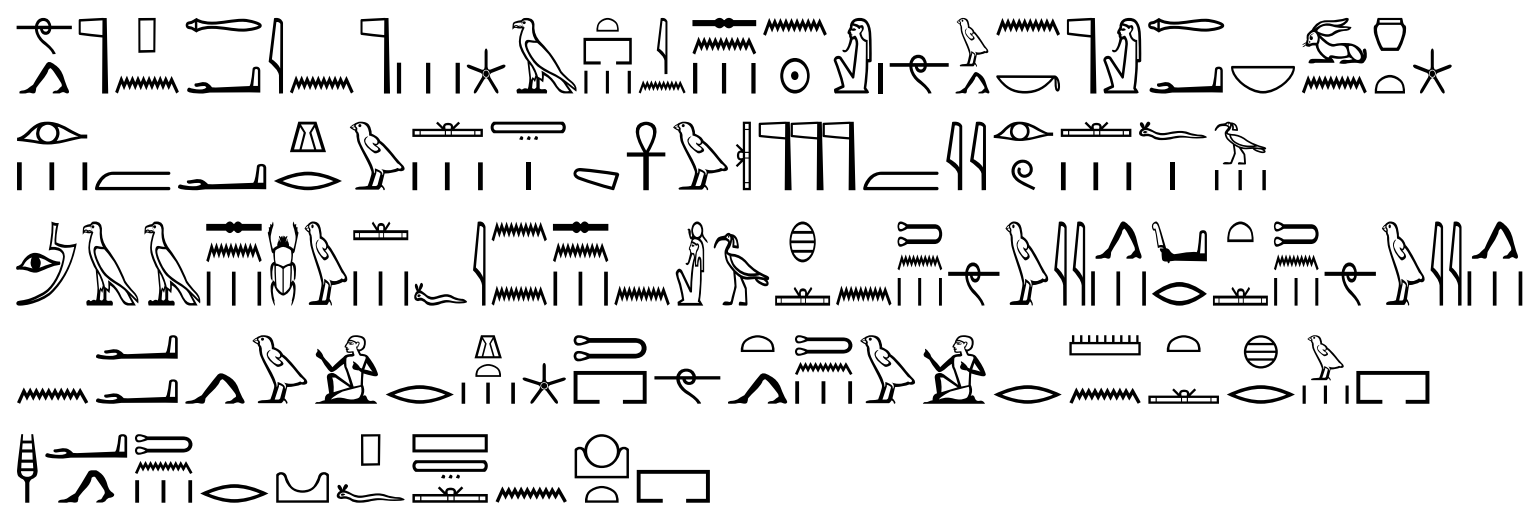

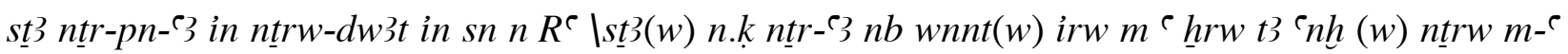

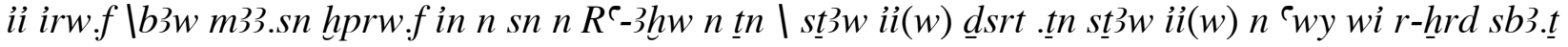

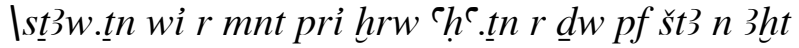

This great god draw by the gods of the underworld by them to Re, draw to you the great god lord of the hours, they made the land bases, the living gods of the earth agree (Wb.I, 37) in his made, they see the soul which, he created the soul to them by the soul of Re to them, they comes strongly, draw me with hands below your star, draw me until to offer up a sacrifice (Wb.I, 529), they raise up to this hill which has the secret the horizon .

\section{Discussion about relation between the $5^{\text {th }}$ hour Amduat and the $5^{\text {th }}$ division book of Gates}

When it was compared between the scene of the middle register of (scene 13) the $5^{\text {th }}$ hour Amduat and (scene 14) and the $5^{\text {th }}$ division book of Gates, it indicate that the scene of middle register (scene 13), of the $5^{\text {th }}$ hour Amduat describes the hill, where the tomb of Sokar -Osiris whereas goddess Isis and Nephtys appear upon the hill while a group of men pulling the Solar boat of Re to reach the hill., Meanwhile (scene 14) of the $5^{\text {th }}$ division book of gates depicts the danger of the evil Serpent "Apep" which prevent the movement the procession of the Solar boat of Re as it was represented in (scene 14), in front of the Solar boat stand four gods dragging the Solar boat while 12 Gods holding the coils to cripples the movement of evil serpent "3pp" The text accompanied (scene 13) middle register $5^{\text {th }}$ hour Amduat inform the soul of the deceased about the mysterious path way to reach the tomb of Sokar, the god of the Necropolis .

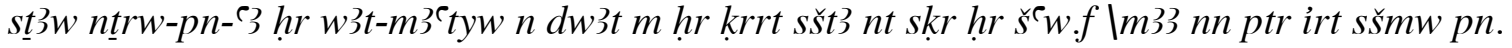

The great God is towed on the paths of Maat of the underworld upon the mysterious Tomb of Sokar upon his sand, which has no view to follow that.

The text accompanied (scene 14) middle register $5^{\text {th }}$ division of the book of the gates mentioned the dangers which will encounter the deceased on his way to the tomb of god Sokar, when god Re appeal the guardian god of this domain and he, gave instruction and advice to the deceased to overcome this danger.

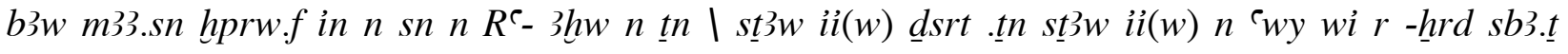

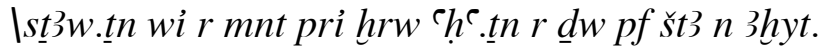


They see the soul which he created the soul to them by the soul of Re to them, they come strongly, draw me with hands below your star, draw me until to offer up a sacrifice, they raise up to this hill which has the secret of king tomb.

\section{The Judgment scene of Osiris on the door of the Gate of the $5^{\text {th }}$ division of the Book of Gates (scene.16).}

The scene of the Judgment of Osiris depicted on the door of the $5^{\text {th }}$ division of the book of Gates on the 4 pillared hall (E) in the tomb of Seti I (Abitz, 1984; Darnell, 2004). Moreover, this scene was depicted on the exterior Lid of the Sarcophagus of King Seti I now in Soane Museum in London (no. PJ 1551.05) (Tylor, 2010).

The upper lintel of the scene is decorated by $h k r$ friezes below it, while Osiris represented seated on a throne, which lead to him by a stairway on its steps are 9 Gods representing the Ennead of Osiris, in front of the figure of Osiris a balance whereas Anubis is represented in front of Osiris, in the upper corner under him a boat inside which figure of a pig, in front of which Monkey figure holding a curved stick (Fig. 11) (Piankoff \& Mystre, 1944).

Manassa (2006) emphasized that the Judgment of Osiris tableau of the book of gates, as the most important Scene of the Book of Gates which represent the deceased king before the figure of Osiris enthroned.

Fig.11: Tableau Judgment of Osiris in the $5^{\text {th }}$ Gate of Book of Gates.

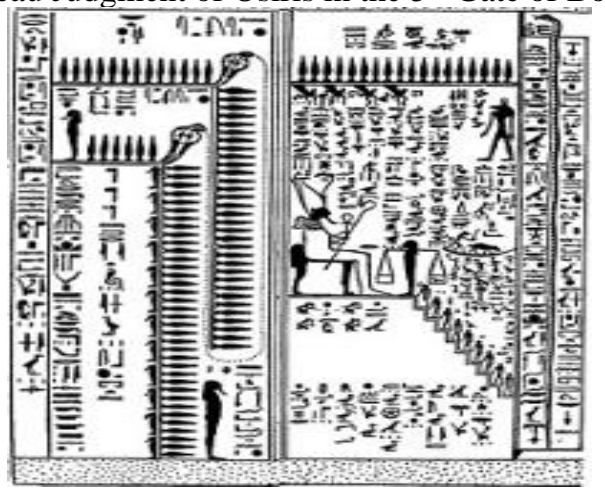

cf., Manassa,C.(2006).The Judgment Hall of Osiris in the Book of Gates, pl.xv.

\section{On the upper lintel of the Scene of the Judgment Hall of Osiris, this text}

$m \underline{d}$ 3.t $n t n d \underline{d}$ sir $m d w 3 t$ Book of protecting Osiris in the Underworld.

Kohler (1975) highlighted the presence of Anubis in the Judgment hall due to the role of Anubis as a judge in the afterlife according to his epithet as "ip-ibw "assessor of heart" as he swallows the heart.

Manassa (2006) determined that Anubis swallow Osiris in order to protect him when he passes over the snake "3pp" This was mentioned also in Spell 99-(a) of the Book of the Dead (you who sails over this Vertebra of Apophis, you who attaches head and makes necks firm by escape from wounds "O" attendant of the mysterious boat, you who restrains Apophis(Allen, 1974). The Upper right corner of the scene of the Judgment Hall contain depiction of a small bark, in which two Monkeys holding sticks, One in act of striking a large Pig his name was written on the figure

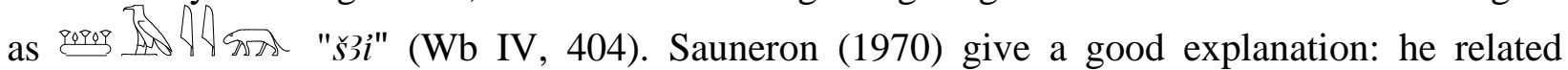
between the scene of the pig who swallow the eye of Horus, which was mentioned in the Magical Papyrus of Brooklyn Museum, with the swallowing Pig in the Judgment Scenes of the Book of gates. (Sauneron, 1970; Borghouts, 1984).

The text accompanied the figure of the boat of the Monkey, indicate that. $m d w m 3^{\top} t y \underline{t} n i(w) w \underline{d}^{\ulcorner}$f $m d w \underline{d} \underline{h} w t y$ 
Word of the Justified (Wb.V, 375) as he renders Judgment Word spoken by Thot.

\section{The figure of gods on the Steps of the Hall of Osiris}

The gods which represented on the steps, they are The Osiris Ennead gods, they possess a dual Solar-Osirian nature, who represented on the lid of the coffin of Seti I.

Psdt imyw Wsir 3hw imyw imntt.

The Enneand whom are in Osiris, blessed spirits who are in the West (Manassa, 2006; Darnell, 2004).

The Figures of The Mummified gods upon the Scale pan in the scene of the Judgment Hall of Osiris

Seeber (1976) suggest that the scale pan in the scene of the Judgement Hall of Osiris in the book of gates remain empty in contrast of the scene of the Judgment of Osiris in Spell 125 of the Book of the Dead so that he suggests that the former Judgment take place on an individual scale (Labrique, 2003).

The relation of the scene of the Judgment Hall of Osiris to the scene of the union of Re with his divine body in the $6^{\text {th }}$ hour of the book of Amduat give us a further evidence about the importance of this scene for the deceased in the $5^{\text {th }}$ division of the Book of Gate. Manassa (2006) determined that the scene of the Judgment Hall of Osiris depicts the triumph of Re over his enemies which is the pattern of weighting heart indicating the purpose of the scales in this scene. (Darnell, 2004), highlighted the benefit of the scene of the Judgment of Osiris in the $5^{\text {th }}$ gate is that a momentous decision concerning the Fate of the Soul of the deceased are made before the Union of the divine power of Re with his body which took place in the $6^{\text {th }}$ hour of Amduat. Otherwise, the proper Judgment in the nighty journey be equated with the Solar emblem standstill " $h^{\curvearrowright "}$ when the evil Serpent 3pep has the Potential power to stop the movement of the Solar boat of Re, so that the scene of the Judgment Hall of Osiris in the Book of Gates reflects conflict of Re against his enemies thus the entire fate of the world is literally hanging in the balance of the Judgment (Darnell, 2004).

\section{The $6^{\text {th }}$ hour of Amduat}

The scenes of the $6^{\text {th }}$ hour of Amduat depicted on the eastern wall of the $2^{\text {nd }}$ annexed room to the left of the burial chamber (M) consist of 3 registers (Lefebure, 1884).

Fig 12: The $6^{\text {th }}$ hour Amduat divided into 3 registers.

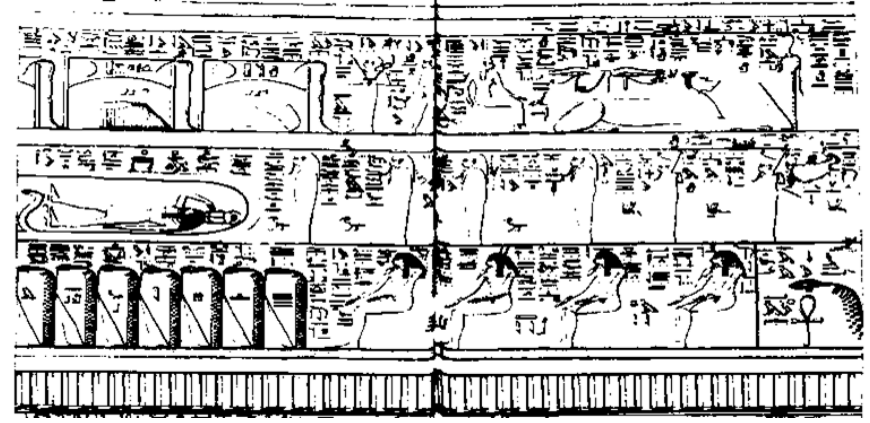

cf. Lefébure, G. Le Tombeau de Seti I, part IV, pl.xli.

The $6^{\text {th }}$ hour of Amduat divided into 3 register, the middle register (scene 16) of the Book of Amduat depicts the corpse of Re represented by reclining figure with a the head of beetle, it is an image of Re when his "Ba" soul is near total depletion, Re is a flesh and also the body of Osiris so when the duality under unity of Re and Osiris occurs, so that the potential power of $\operatorname{Re}$ and Osiris will be rejuvenated.(Hornung, 2007). The text accompanied the scene read as follows : $m$

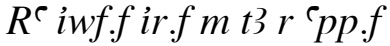


Re body swallow (Wb.I, 184), his flesh, He makes in the earth when he enters.

Hornung (2007) highlighted that the $6^{\text {th }}$ hour of Amduat is the most important event in the Underworld occurs, Whereas the Ba or soul of Re unites with his own body or alternatively with the $\mathrm{Ba}$ of Osiris inside a circle formed by the Serpent goddess $M h n n$ who protect the divine body of Re, this event occurs in the underworld when the sun god begin its regeneration, it is a moment of great significance (Fig.12) (Hornung, 2007).

The relation between (scene 16) of Amduat, middle register $6^{\text {th }}$ hour Amduat and the scene of the Judgment of Osiris in the $5^{\text {th }}$ Gate (scene 16) Book of the Gates which is summarized in after the Judgment of Osiris in the $5^{\text {th }}$ Gate. A momentous decision concerning the fate of the soul of the deceased is made before the union of the divine power of Re with his body which took place in the $6^{\text {th }}$ hour of Amduat when the soul of Re unites with his own body or alternatively with the Ba of Osiris.

The text accompanied the scene of the Judgment of Osiris (scene 16) indicates the importance of the Judgment of Osiris before the union of the Ba of Osiris with his divine body.

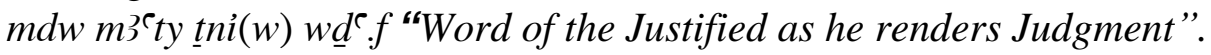

the text which was inscribed on the stairway of the throne of Osiris in (scene 16) indicates that the recreation of the soul of Osiris by the Ennead gods $P$ sdt imyw Wsir 3hw imyw imntt

The Enneads who are in Osiris, blessed spirits who are in the West.

The text accompanied the middle register scene of the $6^{\text {th }}$ hour Amduat (scene 16) refers to the union of the Ba of Re with his body am $R^{\complement}$ iwf.f ir.f $m$ t3 $r$ 'pp.f

Re-body swallow his flesh, he makes in the earth when he enters.

\section{Conclusion}

The researcher highlighted that why certain divisions of the book of Gates are depicted beside some hours of the book of Amduat on the Tomb of King Seti I for the first time on the wall of the Royal Tombs in the $19^{\text {th }}$ dynasty funerary painting scenes due to the scenes and it's explained Text of the book of Amduat, describe the nature of journey of the sun Re which inform the soul of the deceased accompanied the sun god in his journey in the underworld, about the domains of the Underworld the creative and the gods, so that it was considered as a guide for the soul of the deceased. Meanwhile ,the scenes of the book of Gates informs the deceased about the dangers facing him and how to overcome them to enable the soul of the deceased to survive and ensure the continuation of his journey with the sun god in the domains of Underworld until his soul will be resurrected with the sun god, When Re demanded from the guardian god of each gate represented at the End of each division of the book of Gates to open his gate for the Solar boat procession of $\mathrm{Re}$, overcoming all the dangerous spirits. So, it is concluded that during the $19^{\text {th }}$ dynasty the book of Amduat was not sufficient to fulfill the deceased's wish for the survival of his soul, which is summarized in the continuation of his soul's alive until he will be resurrected with the sun god at the end of the journey through the dangers of the underworld, therefore, the first 5 division of the book of Gates appears beside the first 6 hours of the Book of Amduat on the tomb of king Seti I.

The relation between Middle Register scenes Amduat and its Context and scenes of Middle Register scenes book of Gates and it's Context.

\begin{tabular}{l|l|}
$\begin{array}{l}\text { Middle Register scenes Amduat and its } \\
\text { Context. }\end{array}$ & $\begin{array}{l}\text { Middle Register scenes book of Gates and its } \\
\text { Context. }\end{array}$ \\
$\begin{array}{l}\mathbf{1}^{\text {st }} \text { hour Amduat (scene 1) Theme. } \\
\text { the sun god in the form of god Khepri enters }\end{array}$ & $\begin{array}{l}\mathbf{1}^{\text {st }} \text { division book of Gates (scene 2) Theme } \\
\text { the Sun god in the form of (Khepri) approaches }\end{array}$ \\
\hline
\end{tabular}


the gate of the underworld after the sunset.

'rryt imntt nt 3 ht

"entering the Western Horizon.

errwt ntrw th (n) $R^{\top}$ sns.n ntr - $3 \mid$ wn $3 \quad n . k$ imnt št 3 t ir irw

These gods traverse to Re, they praise the great god, open gate of the underworld for me.

\section{Common context}

snš 3 n.k Зwy-niwt wrt |shd kkwt srk htmt । 'rr.k m rn.k n $R^{\top} r$ bw hr Wsir-hnty-imnty

Open your gateway of the great city, light the darkness, you make the place of the hereafter breathe, you ascend in your name of Re to the place were Osiris, the foremost of the underworld.

\section{$2^{\text {nd }}$ hour Amduat (scene 4) theme}

the Solar boat of Re trans versing the Watery river of Osiris Wrns, the sun god in the form of Atum-Re

\section{Context}

the soul of the deceased sail with the sun god through Osiris river and the deceased asked from $R e$ to receive his soul on the gateway and to give his soul live

$\underline{d} d m d w$ in $d 3 w t$ ntrw- $3 w$ pn.l'k.f m.i $r \underline{d r}$ ?

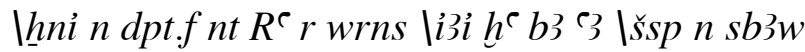

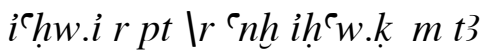

Speech of the great gods of the underworld, he come in with me to the edge of the gate, he sails in his boat of Re to Wernes, adore the great shining soul, receive on the doors of the gate my flesh, body, ascend to sky, live to your flesh on the earth.

\section{$3^{\text {rd }}$ hour Amduat (scene 7) Theme}

the Solar boat complete trans versing the watery river which called Wrns,

\section{Context}

describing the sun god, while sailing trans versing the watery river (Wernes)

dd $m d w$ in $n t r w-s t 3 w$ ht.f ntr-pn-? | $\mathrm{k} m$ iți tw hni.f $n$ dpt.f nt itrw the Underworld western mountain gate.

Re call "smt"to open the gate.

in $R^{\mathrm{C}} \mathrm{n}$ smt $h \underline{d}$ smt psdt imw.i

Re says to god "smt" (the Western mountain god), brighten(smt), the Ennead among them I am,

\section{Common context}

in nn $n$ wsrwt -ntrwt th $w \underline{d} m d w$ ntr-e $\underline{t}$ ts $n . f$ $h^{\complement} w$. $\mathrm{m}$ rk rnw. $(f)$ im $f$

These powerful gods say according to the command of the great gods, collected to him his members, by the names of him he is there.

\section{$2^{\text {nd }}$ division book of Gates (scene 5) theme}

The sun god in the form of a Ram headed God Atum-Re is towed by four men to the riverbank.

\section{Context}

Re call up the guardian gods of the riverbank Wernes and asked from them to protect his boat when he arrives to that area

st 3 ntr $-p n-e_{3}$ in ntrw-dw3t $\mid$ spr in ntr-pn - $3 r$ dpt-t3 dptw-ntrw in $n$ sn $R^{\top}$ |ntrw grw dpt t3.f

The great god draw by the underworld gods this god arrive to the land of sailing, the god's boats belongs to Re, moreover the gods sails in his land.

\section{$3^{\text {rd }}$ division Book of Gates (scene 8) Theme}

The Solar boat is towed by four Men, the sun

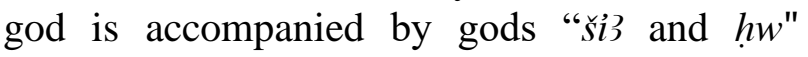
complete trans versing the river Wrns.

\section{Context}

the sun god asked from the underworld guardian gods of the river Wernes to help the soul of the deceased to transverse the river.

st 3 ntr - 3 pn in ntrw- $d w 3 t \mid$ skdw $m$ š r-pr ir hrw st $3(w)$ tn wi dw3t Im33. n ir.n wdn 'wy.tn 
Speech of the secrets of the gods possessed by this great god,he comes seizing ,he sails in his boat of the river.

\section{$4^{\text {th }}$ hour Amduat (scene 10) theme}

The Solar Boat of Re reaches a region called " imHt" Sandy area of Sokar.

\section{Context}

describe the difficult sandy pathway through which the solar boat of Re path through.

imntt st 3 w iw rh sšm pn $n$ w3t št $n t$ r r $3-s t 3 w m$ tn $n w$ w3t(w)-dsrw $n$ imht

The hidden mysterious to know this guide to the mysterious road of the Region Restaou with you of the roads of Deserou of (the Region Imhet.

\section{$5^{\text {th }}$ hour Amduat (scene 13) theme}

depicts the hill were the Tomb of Sokar Osiris, whereas goddess Isis and Nephtys appear upon the hill while a group of men pulling the solar boat of Re to reach the hill.

\section{Context}

inform the soul of the deceased about the mysterious pathway to reach the tomb of god Sokar the god of the Necropolis.

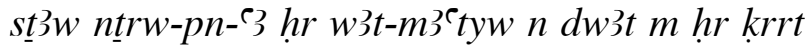

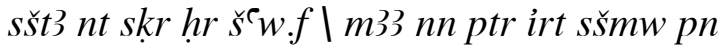

The great god is towed on the paths of Maat of the underworld upon the mysterious tomb of Sokar upon his sand, which has no view to follow that. st $3(w) . t n$ wi im sn

the great god pull me to the underworld gods, the youthful sailors to the chapel making voice they pull me to the underworld they decided to install their arms to drag me to them there.

\section{$4^{\text {th }}$ division book of Gates (scene 11) Theme}

The Solar boat is towed towards 9 Shrines containing Mummified gods they named "the gods who follow Osiris to the Tomb of Sokar

\section{Context}

Re appeal the guardian gods on his pathway of the Necropolis to open the pathway of the Gate.

st3.tn mn 'wy.tn ph.tn $3 h n$ b3w $r$ n ii.tn $3 h w n$ b3w.tn |w3క̌ $n$ ibw.tn |wn 3.tn w3t-nfrt $r \quad k r$ $h t(w) \breve{s} t 3$ hr.th

they draw with fixed hands their spirit reached their souls, their spirit comes to their souls, be stronger their heart, open their good gate pathway which have more bend, the mysterious is behind them

$5^{\text {th }}$ division book of Gates (scene 14) Theme represent the Solar boat of $\mathrm{Re}$, on its front stand four gods towing the Solar boat while 12 gods holding the coils to cripples the movement of evil Serpent "ک3pp"

\section{Context}

mentioned the danger which will encounter the deceased on his way to the Tomb of god Sokar, when $\mathrm{Re}$ appeal the guardian god of this domain and he gave instruction and advice to the deceased to overcome this danger.

b3w m33.sn hprw.f in n.sn n.R -3hww n.tn $s t 3 w$

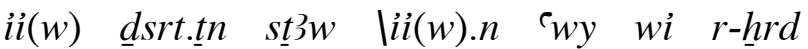

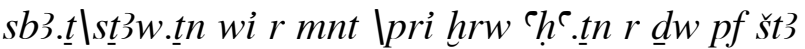
$n$ 3ht.

they see the soul which he created the soul to them by the soul of Re to them, they come strongly, draw me with hands below your star, draw me until to offer up a sacrifice, they raise up to this hill which has the secret of the horizon. 


\section{$6^{\text {th }}$ hour Amduat (scene 16) Theme}

The potential power of Re and Osiris will be rejuvenated.

The scene depicts the corpse of $\mathrm{Re}$ represented by reclining figure with the head of beetle, $\mathrm{Re}$ is a flesh and also Osiris so that duality under unity of Re and Osiris occurs.

\section{Context}

refers to the union of the $\mathrm{Ba}$ of $\mathrm{Re}$ with his body.

'm-R` iwf.f ir.f $m$ t3 $r^{\text {` } p p . f}$

Re- body swallow his flesh, he makes in the earth, when he enters.
Scenes of the Osiris Judgment (scene 16) at Gate $5^{\text {th }}$ division

Osiris seated on a throne lead to it a staircase, on the steps are 9 gods in front of Osiris a balance.

\section{Context}

It indicates the importance of the Judgment of Osiris before the union of the $\mathrm{Ba}$ of Osiris with his body.

mdw mAaty Tni(w) wDa.f

Word of the Justified as he renders Judgment.

The text indicates that the recreation of the soul of Osiris by the Ennead gods

Psdt imyw Wsir -3hww imyw imntt.

The Ennead who are in Osiris,blessed spirits who are in the West

\section{References}

Barguet, P. (1972). L'am -Doat et les funerailles royal. RdE. 24, 7-38.

Borghouts, J., F. (1984). Studien zu Sprache und Religion Ägyptens zu Ehren von Wolfhart Westendorf. vol. II

Bucher, P. (1931). Les Textes à la fin des première, deuxième et troisième heures du livre de ce que il y a dans la Dout. BIFAO.30,230-242

Darnell, J., C. (2004). Enigmatic Netherworld. The Solar Osirian Unity, Cryptographic composition from the Tombs of Ramses VI, OBO .198, 29-33.

Frankfort, H. (1933). The Cenotaph of Seti I at Abydos. vol. II. London.

George, B. (1972). Versuche zur Gewinnung eines Ägyptischen Menschenbildes aus dem Weltbild des Amduat im Rahmen der Vergleichen Religionswissenschaft. GM 3, 15-25

Goyon, J-C. (1927). Rituels funéraires de l'Ancient Egypt. Paris.

Hornung, E. (1963). Das Amduat, vol. I. Wiesbaden

Hornung, E. (1964). Das Amduat. Die Schrift des verborgenen Raumes BdE 7,.3-11.

Hornung, E. \& Teichmann, F. (1971). Das Grab des Haremhab im Tal der Konige,

Hornung, E. (1987). Text zum Amduat, vol. I, in: (Aegyptiaca Helvetica. 3).

Hornung, E. (1992) Zum Grab Sethos in seinem ursprunglichen Zustand, in: Studies in Egyptology,.91-98.

Hornung, E., \& Christian, E. (2006). The Tomb of Thutmose III.

Hornung, E. (2007). The Egyptian Amduat, the book of the Hidden Chamber.Zurich.

Hornung, E. (2014). The Egyptian book of Gates. Zurich.

Regen, I. (2014). The Amduat and the book of Gates in the tomb of Padiamenope (TT 33), A work in progress, in: Thebes in the First Millennium B.C. Cambridge.

Regen, I. (2014). Metatextuality and efficiency in Ancient Egypt, two examples from the Priest Padiamenope Tomb. Book of the Gate, TT.33, Second hour, OLA 232.

Kohler, U. (1975). Untersuchungen zur Darstellung und Bedeutung eines mit Anubis verbundenen religiösen Symbol (GOF. IV) vol. I, .384-395.

Lefébure, G. (1884). Le Tombeau de Seti I. MMAF II. Paris. 
Leitz. Chr. (2002). Lexikon der Ägyptischen Götter und Göttern Bezeichnung. vol. VI. (OLA.115)

Manassa, C. (2006). The Judgment Hall of Osiris in the Book of Gates. RdE 57,.109-150.

Piankoff, A. (1934). The Sky Goddess Nut and the Night journey of the Sun. JEA. 20,.57-70.

Piankoff, A. \& Mystre, C. (1939). Le Livre de Portes. Vol. I, MIFAO.73

Piankoff, A.\& Mystre, C. (1944). Le Livre de Portes Vol II. MIFAO.74.

Piankoff, A. (1952). Les Chapelles des Toutankhamon. MIFAO .75.

Piankoff,A .(1954) .The tombe of Ramses VI.(Bollingen series.40).New York.

Piankoff, A (1957). La tombe de Ramses I. BIFAO 56,189-200.

Piankoff, A. (1957). The Mythological Papyri, in: (Bollingen Series.40)

Piankoff, A. (1962). Les composition theologique du Novel Empire egyptienne. BIFAO.62, 121128

Piankoff, A. \& Hornung, E. (1966). Das Grab Amenophis III im Westal der Konig. MDAIK 17, 111-127.

Pirenne,J.(1965). La religion et la morale de l'Egypte antique, Paris.

Sadek,Abd -Aziz.(1985).contribution á l'étude de l'Amdouat, le variant tardives du livre de l'Amdout, Zurich.

Sauneron,S.(1970). Le Papyrus Magique illustre de Brooklyn Museum, (47, 218, 156).

Seeber,C.(1976).Untersuchungen zur darstellung des Totengericht im Alten Agypten, MÄS 35.

Schweizer, A. \& Hornung, E. (19 94). Seelenfuhrer durch den Verbargenen Raum, Das Ägyptische Unterwelt Amduat, Munchen.

Tylor, J.H. (2010). Journey through the Afterlife in the Egyptian Book of the Dead. London.

Tylor, J, H. (2017).in:Sir John Soane 's Greatest Treasures the Sarcophagus of Seti I. London . Wb= Erman,A. \& Grapow, H.(1971).Wörterbuch der Ägyptischen Sprache, vols. I, II, III, IV, V Berlin.

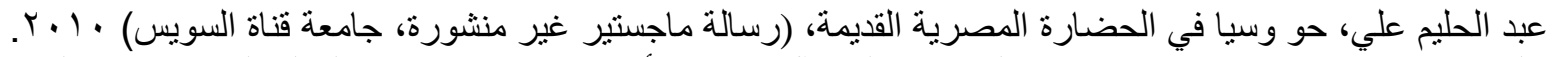
علي محفوظ عباس حسن، تصوير كتاب البوابات على الآثار منذ نشأته وحتى نهاية عصر الدولة الدئة الحديثة، (رسالة ماجستير

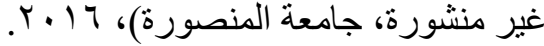

ماجدة السيد عبد الهادي، العالم الأخر ومكانه في المفهوم المصري القديم (رسالة دكتوراه، غير منشورة جامعة القاهرة)، r.P 